\title{
HOPE FOR WHOM? \\ FINANCIAL AID FOR THE MIDDLE CLASS \\ AND ITS IMPACT ON COLLEGE ATTENDANCE
}

\author{
Susan Dynarski \\ Working Paper 7756 \\ http://www.nber.org/papers/w7756 \\ NATIONAL BUREAU OF ECONOMIC RESEARCH \\ 1050 Massachusetts Avenue \\ Cambridge, MA 02138 \\ June 2000
}

I appreciate the helpful comments of Daron Acemoglu, Joshua Angrist, David Autor, Julie-Anne Cronin, Amy Finkelstein, Jonathan Gruber, Thomas Kane, Steve Pischke, James Poterba and participants of the NBER Summer Institute and Economic Effects of Taxation meetings. Support from NBER Aging and Health Pre- and Post-Doctoral Fellowships and the Smith-Richardson Foundation is gratefully acknowledged. The views expressed herein are those of the author and not necessarily those of the National Bureau of Economic Research.

(C) 2000 by Susan Dynarski. All rights reserved. Short sections of text, not to exceed two paragraphs, may be quoted without explicit permission provided that full credit, including (C) notice, is given to the source. 
Hope for Whom? Financial Aid for the Middle Class and Its Impact on College Attendance

Susan Dynarski

NBER Working Paper No. 7756

June 2000

JEL No. I22, J24

\begin{abstract}
$\underline{\text { ABSTRACT }}$
The federal government and the states have recently enacted a slew of aid policies aimed at college students from middle- and high-income families. I estimate the impact of aid on the college attendance of middle- and upper-income youth by evaluating Georgia's HOPE Scholarship, the inspiration of the new federal Hope Scholarship. The results suggest that Georgia's program has had a surprisingly large impact on the college attendance rate of middleand high-income youth. Using a set of nearby states as a control group, I find that Georgia's program has likely increased the college attendance rate of all 18- to 19 -year-olds by 7.0 to 7.9 percentage points. The results suggest that each $\$ 1,000$ in aid $(\$ 1998)$ increased the college attendance rate in Georgia by 3.7 to 4.2 percentage points. Due to key differences between the federal and Georgia programs, these estimates should be treated as a generous upper bound on the predicted effect of the federal Hope Scholarship. Further, the evidence suggests that Georgia's program has widened the gap in college attendance between blacks and whites and between those from low- and high-income families. The federal Hope Scholarship, should it have its intended effect on middle- and upper-income attendance, will also widen already large racial and income gaps in college attendance in the US.
\end{abstract}

\author{
Susan Dynarski \\ Kennedy School of Government \\ Harvard University \\ 79 JFK Street \\ Cambridge, MA 02138 \\ and NBER \\ susan_dynarski@harvard.edu
}




\section{Introduction}

Federal and state governments have recently ushered in a new generation of student aid policies. The largest of these new programs are the federal tax incentives known as the Hope Scholarship and Lifetime Learning Credit, which allow families of college students to offset their educational costs with tax benefits of up to $\$ 1,500$ a year. For the 1998 tax year, a total of $\$ 3.5$ billion was delivered to 4.8 million families through these two programs, making them one of the largest sources of federal subsidies for college students. ${ }^{1}$ A second federal initiative, the Education IRA, allows families to put after-tax dollars into college savings and accumulate interest tax-free. The federal programs join a wide array of aid programs introduced by the states. Many states now have tax-free college savings plans and several have introduced tuition tax credits. State-funded merit-based scholarships are the latest student aid fashion to sweep across the states, with more than a dozen legislatures considering such programs. Georgia's HOPE (Helping Outstanding Students Educationally) Scholarship, the namesake and inspiration of the federal program, is the largest and best known of the state merit scholarships.

All of these new state and federal programs differ from traditional student aid in one crucial aspect: they are not need-based. Historically, government aid for college has been strongly focused on low-income students. Eligibility for the two largest federal aid programs, the Pell Grant and Stafford Loan, is determined by a complex formula that defines financial need on the basis of income, assets and family size. The formula is quite progressive: 90 percent of dependent students who receive federal grants grew up in families with incomes less than $\$ 40,000 .^{2}$

\footnotetext{
${ }^{1}$ Estimate based on initial analysis of 1998 tax returns provided by Julie-Anne Cronin of the Office of Tax Analysis, US Department of Treasury. By way of comparison, during the academic year 1997-98 students received \$6.3 billion in Pell Grants (College Board, 1998).

${ }^{2}$ Calculated from data in Table 314 in National Center for Education Statistics (1998a).
} 
By contrast, the new aid programs are aimed squarely at middle-and high-income families. Taxdeferred savings plans most benefit upper-income families, who both face the highest marginal tax rates and have the highest saving rate. The federal Hope Scholarship and Lifetime Learning Credit have three key characteristics that limit their benefit to low-income families. First, the income cutoffs for eligibility for the subsidies are set high enough that less than ten percent of filing households exceeds them. ${ }^{3}$ Second, allowable educational expenses are offset by any need-based aid received. As a result, a student who attends the typical two-year college and is poor enough to receive the maximum Pell Grant receives no Hope Scholarship. Third, the subsidy takes the form of a non-refundable tax credit, so that a family too poor to pay taxes receives no Hope Scholarship.

How will this new breed of student aid affect college attendance rates? Will aid to middle- and high-income families actually increase college attendance, or will the new programs simply transfer funds to infra-marginal students? We have little evidence with which to answer these questions. There is scant research concerning the impact of tuition subsidies on middle- and upper-income youth, for the simple reason that most existing aid programs focus on needy students. History has therefore provided few experiments that would allow us to measure the responsiveness to aid of middle- and upper-income youth. There are reasons to suspect that low- and upper-income youth respond differently to aid: wealth, parental education and academic preparedness are all tightly correlated with income and each have their own impact on the decision to attend college. And as I will show later in the paper, a fairly simple model of human capital investment suggests that the effect of aid on schooling decisions will vary by parental income.

In this paper, I estimate the impact of aid on the college attendance of middle- and upper-income students by evaluating the program that is the namesake and inspiration of the federal Hope Scholarship:

\footnotetext{
${ }^{3}$ The income cap is set at an adjusted gross income of $\$ 100,000$ for married-couple families and $\$ 50,000$ for single filers. Early analysis of 1997 tax returns indicates that only 7.4 percent of household tax returns fell above these income cutoffs; this estimate is expected to rise somewhat as late returns are tabulated (Hollenbeck and Kahn, 1998).
} 
the Georgia HOPE (Helping Outstanding Pupils Educationally) Scholarship. In 1993, Georgia initiated HOPE, which is funded by a state lottery. The program allows free attendance at Georgia's public colleges for state residents with at least a B average in high school. ${ }^{4}$ More than a dozen states are weighing the introduction of merit scholarships like Georgia's and governors in Alabama and South Carolina were elected in 1998 on the basis of pledges that they would initiate lotteries to fund education in their own states (Selingo, 1999). Despite the widespread attention paid Georgia's HOPE Scholarship, there has been no rigorous evaluation of its impact upon college attendance. ${ }^{5}$ Do programs such as Georgia's HOPE actually increase college enrollment? Or do they simply transfer funds to families who would have sent their children to college anyway?

I use data from the Current Population Survey to evaluate the impact of Georgia's HOPE Scholarship on college attendance. Using a set of nearby states as a control group, I find that Georgia's program has likely increased college attendance rates among all 18- to 19 -year-olds by 7.0 to 7.9 percentage points. I obtain similar results using a within-state control group to estimate the program's effect.

I further find that the increase is concentrated among Georgia's white students, who have experienced a 12.3 percentage point rise in their enrollment rate relative to whites in nearby states. The black enrollment rate in Georgia appears unaffected by HOPE. The differential impact of HOPE on blacks and whites is likely due to the focus of HOPE on middle- and upper-income students who perform well in high school.

\footnotetext{
${ }^{4}$ The federal Hope Scholarship in its proposed form also required minimum grades in high school, but this provision was dropped over concerns about the cost and propriety of having the Internal Revenue Service gather high school transcripts.

${ }^{5}$ The Council for School Performance of Georgia State University has conducted a number of studies of HOPE. These studies contrast the academic performance of HOPE recipients with that of college students who don't get HOPE. Since HOPE scholars are selected on the basis of academic merit, these studies do
} 
Among the subset of youth that is most likely eligible for Georgia HOPE - those from upperincome families - I find the attendance rate has risen 11.4 percentage points relative to that of a similar population in nearby states. There has been no relative rise in attendance among youth from lower-income families. However, these last estimates should be treated with caution, as the analysis indicates that the sub-sample of youth for whom family-income data is available is non-randomly selected. This particular estimate, unlike the others of the paper, may therefore be biased by sample selection.

Overall, the results suggest that for each $\$ 1,000$ of subsidy the college attendance rate of middleand upper-income youth rises by four to six percentage points. This is a surprisingly large response: the estimate is of the same order of magnitude as those reported by studies that examine the effect of aid on low-income students. It is of interest to calculate the share of HOPE funds that are going to marginal and infra-marginal students. The college attendance rate in Georgia before HOPE's introduction was 29.9 percent. The estimates of the paper indicate that HOPE increase this rate by seven to eight percentage points, suggesting that about 20 percent of post-HOPE college attendance by 18 - to 19 -year-olds was induced by HOPE. Roughly, then, about 80 percent of HOPE funds flow to those who would have gone to college in the absence of the subsidy. While the average HOPE Scholarship paid for those at Georgia's colleges and universities is $\$ 1,900$, four inframarginal students must be subsidized in order to induce one into college.

The results should be extrapolated to other states and programs with caution. Georgia had attendance rates well below the national average before HOPE was introduced, and it is possible that a similar program in a high-attendance state such as Massachusetts would not have a similar impact. Further, Georgia's program is unusual in its simplicity, scale and publicity. A less transparent form of subsidy - such as a tax credit or tax-free interest on college savings - may not produce responses of similar magnitude.

The HOPE Scholarship has also affected another margin of educational decision-making: the choice of college. Using institutional data from the University System of Georgia and the federal 
Department of Education, I find that HOPE has increased the likelihood that Georgia students will attend college in their home state. As a result, the University System of Georgia has seen an increase in the share of its students who are from the state; this effect is most pronounced in the state's most selective four-year public colleges. In particular, fewer Georgia students now attend college in the states that border Georgia. At the ten schools in Georgia's border states that draw the most Georgia freshmen, enrollment of Georgians dropped from 17 percent of freshmen enrollment in 1992 to nine percent in 1998.

The paper is organized as follows. Section II provides a short overview of the literature on the effect of subsidies on college enrollment and offers a theoretical motivation for why we might suspect that the effect of a subsidy varies with family income. Section III discusses Georgia's program in detail. Section IV explains the empirical methodology and data used in the analysis. Section V presents results. Section VI explores the policy implications of the paper's findings and Section VII concludes.

\section{Background and Literature Review}

A long literature attempts to identify the effect of aid on college attendance. Leslie and Brinkman (1988) review studies whose estimates indicate that $\$ 1,000$ in aid increases college attendance rates by three to five percentage points. ${ }^{6}$ The effect of aid on college attendance is generally poorly identified in these studies. Identification is an important consideration in this context, because aid is correlated with many observable and unobservable characteristics that have their own influence on education. Dynarski (1999) reviews a handful of well-identified studies that use a discrete shift in aid policy as a source of exogenous variation in aid. Kane (1994) finds that a $\$ 1,000$ drop in public tuition increases college attendance by about four percentage points. Reyes (1995) finds that $\$ 1,000$ in loan subsidy increases college attendance by 1.5 percentage points; this relatively low response may indicate that youth do not fully recognize the subsidy value of a loan. Dynarski (1999) exploits variation produced by the elimination in the early 1980s of the Social Security Student Benefit Program, which annually provided

\footnotetext{
${ }^{6}$ All dollar figures in the paper are converted to real 1998 values.
} 
aid to nearly one million college students. She finds that $\$ 1,000$ in aid increases college attendance by four percentage points.

None of these studies, however, focuses on the effect of a price subsidy on middle- and upperincome students. ${ }^{7}$ A recent study by Kane (1999b) focuses most closely on the question posed by this paper. Kane uses longitudinal data to examine how the effect of public tuition on college attendance varies by family income. Exploiting variation in tuition across and within states, Kane finds that a $\$ 1,000$ drop in tuition increases the attendance rate of lower-income youth 5.2 percentage points more than it does that of middle- and upper-income youth.

\section{Modeling the Relationship between Aid, Income and Schooling}

In policy discussions of the effect of aid on education, it is often assumed that low-income students are most responsive to aid. It is loosely argued that low-income students are liquidity-constrained - that is, that they face interest rates that are higher than market rates - and will therefore respond most elastically to a given subsidy to college costs. However, it is straightforward to demonstrate that while adding liquidity constraints to a simple human capital model does predict that liquidity-constrained youth will invest less in education, it does not yield the prediction that constrained and unconstrained youth will respond any differently to a given subsidy to college costs. We require a more nuanced treatment of the interaction of income, interest rates and college costs in order to develop theoretical insight into how high- and low-income students will respond to aid.

In this section, I develop a model of schooling investment that suggests that the effect of aid on schooling will vary by income. The key assumption of the model is that the level of debt that a college student must assume for an additional year of schooling is a decreasing function of his family's income. Higher levels of debt lead to higher interest payments, which increase the college costs of low-income

\footnotetext{
${ }^{7}$ Reyes (1995) examines the effect of subsidized loans on middle- and upper income students, but her estimate will not inform us of the effect of grant aid if youth are debt-averse or do not fully recognize the subsidy value of a low-interest loan.
} 
students relative to those of high-income students. By reducing both the present price of college and the level of debt on which interest is paid, aid increases the optimal level of schooling. Aid's effect on schooling decisions is predicted to drop or remain constant as income rises; which of these predictions holds depends on whether marginal interest rates rise or remain constant as the level of debt increases. The rest of this section lays out the detail of the model and discusses its implications.

Earnings are assumed to be an increasing, concave function of schooling:

(1) $y(S)=\alpha+\beta S-\delta S^{2}$

In this equation, $S$ is years of schooling, $y(S)$ is earnings and both $\beta$ and $\delta$ are positive. This equation describes the observed empirical relationship between earnings and schooling. Differentiating Equation (1) with respect to schooling yields the marginal benefit of a year of schooling:

$$
M B=y^{\prime}(S)=\beta-2 \delta S
$$

In other words, an additional year of schooling yields a return that drops with each year of schooling obtained. The marginal cost of schooling consists of a year's tuition net of any student aid, interest charged on any borrowing and an individual-specific parameter that reflects heterogeneity in the ease with which an additional year of school is completed:

\section{(3) $\quad M C=p(1-A)+R(B)+\gamma_{i}$}

Here, $p$ is annual tuition, $A$ is the percentage of annual tuition that is offset by student aid. $\boldsymbol{\gamma}_{i}$ is the individual-specific, non-financial cost of college. For example, $\gamma_{i}$ may reflect academic preparation for college-level work. $R(B)$ is the total interest rate paid when borrowing amount $B$. I will discuss the characteristics of the $R(B)$ function shortly.

A student's borrowing is determined by the price of college, living expenses, the amount of aid, and the amount that his family can contribute to his education. Parents devote a fixed proportion of income, $\alpha$, to their child's education. The amount borrowed is then:

$$
B=p(1-A)+C-\alpha Y
$$


Here, $Y$ is parental income and $C$ is living expenses other than tuition. ${ }^{8}$ A positive value of $B$ indicates a student who borrows for college, while a negative value indicates a combination of prices, family income and aid that allows a family to forgo borrowing and instead save.

Setting equal the marginal benefit and cost of college, solving for $\mathrm{S}$ and taking the derivative of schooling with respect to aid yields:

$$
\text { (5) } \frac{d S}{d A}=\frac{p+p R^{\prime}(B)}{2 \delta}
$$

This term is unambiguously positive: aid increases schooling. The effect of aid works through two channels, which I will refer to as the price effect and the liquidity effect. The price effect of aid is represented by the first term in the numerator: aid reduces the price of a year of college and thereby increases demand for schooling. The liquidity effect is represented by the second term: aid reduces borrowing and total interest paid and thereby increases the impact of aid on schooling decisions. Both of these effects are scaled by the $\delta$ term, which represents the rate at which the return to schooling drops as the level of schooling rises. If returns drop quickly (that is, $\delta$ is large), then schooling choice will be relatively insensitive to aid. Conversely, if returns drop slowly then aid will have a relatively large effect on schooling choices.

We are interested in how the response of schooling choice to aid varies by family income. Taking the derivative of Equation (5) with respect to income yields

$$
\frac{d^{2} S}{d A d Y}=-\frac{\alpha p}{2 \delta}\left[R^{\prime \prime}(B)\right]
$$

The sign of this term depends on the shape of the interest function, $R(B)$. Recall that $R(B)$ is the total interest that is paid when borrowing amount $B$. If $R^{\prime \prime}(B)$ is positive, then Equation (7) is negative,

\footnotetext{
${ }^{8}$ Note that living expenses affect the level of debt but do not directly enter the marginal cost equation. This is because living expenses are incurred whether or not an individual attends college, and so are not considered a marginal cost of attending college. However, interest is paid in order to fund living expenses only if a person attends college and so in this case constitutes a marginal cost of schooling.
} 
implying that the effect of aid decreases as income rises. $R^{\prime \prime}(B)$ is positive if students face marginal interest rates that rise with borrowing.

There is evidence that students and families face rising interest rates when borrowing for college. ${ }^{9}$ The cheapest source of funds for most families is federally subsidized student loans: the interest rate is about seven percent, and the government pays all interest while the student is in school. For a student borrowing the maximum of $\$ 17,125$ and repaying over ten years, a loan with a nominal rate of seven percent and an in-school interest subsidy is equivalent to a standard loan with a nominal rate of 4.5

percent. ${ }^{10}$ For most families, housing equity is the next cheapest source of funds. ${ }^{11}$ Current mortgage rates are about eight percent; the preferential tax treatment of mortgage interest implies an effective rate of six percent for those in the 28 percent tax bracket. If housing equity has been exhausted, families can turn to unsubsidized federal loans, which charge a rate of seven to eight percent but require that interest be paid while the student is in school. As a last resort, families can turn to more expensive sources of funds, such as unsecured personal loans, retirement savings and credit cards. It is plausible, then, that students face interest rates that rise with their borrowing. Equation (6), in this case, predicts that the effect of aid on schooling will diminish as income rises.

The effect of aid does not vary by income if interest rates remain constant as the level of borrowing rises. In this case, Equation (6) is equal to zero. The effect of aid will actually increase with income if marginal rates decline with the level of borrowing, but I ignore this case since such a pattern of interest rates is implausible. The model therefore predicts that, for each individual, the effect of aid either drops or remains constant as income rises.

\footnotetext{
${ }^{9}$ This paragraph draws on Kane (1999b).

${ }^{10}$ Recent changes in tax law further increase the subsidy value of federal loans. As of 1998, borrowers can deduct $\$ 1,000$ a year in loan interest from taxable income if their adjustable gross income falls below $\$ 40,000$ (single taxpayers) or $\$ 60,000$ (married taxpayers).

${ }^{11}$ Housing equity is the cheapest source of capital for high-income families because of their high marginal tax rates. Further, those from the highest-income families are not eligible for subsidized loans.
} 
However, as I will explain with an example, Equation (6) does not unambiguously predict that at least as large a share of low-income youth as high-income youth will be induced to attend college by a given subsidy. ${ }^{12}$ Say that the individual-specific, non-financial cost of schooling $\left(\boldsymbol{\gamma}_{i}\right)$ is identically and normally distributed within the low-income and high-income populations. ${ }^{13}$ The college attendance margin will cut at a higher point in the $\boldsymbol{\gamma}_{i}$ distribution among high-income youth than it will among lowincome youth. This is because among high-income youth the reduced level of debt (and therefore interest payments) that their parents' financial contribution to their schooling allows can offset relatively high non-financial costs of college. ${ }^{14}$

How does this affect our parameter of interest, the relative shares of high- and low-income youth induced by a subsidy to attend college? The share of an income group that is pushed over the college attendance margin is a function not only of the sensitivity of that group to aid but also the proportion of the group near the margin of college attendance. If the distribution of $\gamma_{i}$ is normal (or, more generally, non-uniform) it is ambiguous whether the share that is close to the margin of attendance is larger among low- or high-income youth. For example, the college attendance margin among high-income youth might appear at the mean of the $\gamma_{i}$ distribution, where the largest share of the group is concentrated. The college attendance margin among low-income youth will then appear below the mean of the $\gamma_{i}$ distribution, where a smaller share of the group is concentrated. In this case, a given subsidy could easily

12 Thanks to David Autor for drawing this to my attention. Stanley (1999) discusses this point in the context of the G.I. Bill, which he finds had its largest impact on the schooling of veterans who grew up in families of high socioeconomic status.

${ }^{13}$ Normalcy is not required here; any non-uniform distribution will produce the same conclusion.

${ }^{14}$ Ellwood and Kane (1999) show that even after controlling for test scores (a measure of the nonfinancial costs of schooling, $\boldsymbol{\gamma}_{i}$ ) low-income students are less likely to go to college than high-income students. This is evidence that the college attendance margin cuts at a higher point in the $\gamma_{i}$ distribution of high-income youth than low-income youth. The paper also shows that low-income families contribute less money to their children's education than high-income families and that this differential is not fully offset by the greater levels of aid received by low-income students. This indicates that low-income students do, therefore, face higher borrowing requirements than do high-income students. 
push into college a larger share of high-income youth than low-income youth. It is simple to construct a scenario in which the opposite is true.

The effect of aid on the schooling decisions of middle- and high-income youth must therefore be determined empirically, rather than extrapolated from aid's effect on low-income youth. In the next section, I discuss the policy experiment that will be used to estimate the impact of aid on the college attendance rates of upper-income youth.

\section{Georgia's HOPE Scholarship}

In 1991, Georgia Governor Zell Miller requested that the state's General Assembly consider the establishment of a state-run lottery, with the proceeds to be devoted to education. The Georgia General Assembly passed lottery-enabling legislation during its 1992 session and forwarded the issue to voters, who approved the required amendment to the state's constitution in November of 1992. The first lottery tickets were sold in June of 1993. \$2.5 billion in lottery revenue has flowed into Georgia's educational institutions since 1993. The legislation and amendment enabling the lottery specified that the new funds were not to crowd out spending from traditional sources. While it is not possible to establish conclusively that such crowd-out has not occurred, spending on education has risen substantially since the lottery was initiated, both in absolute dollars and as a share of total state spending. Roughly equal shares of lottery funds have gone to four programs: the HOPE Scholarship, educational technology for primary and secondary schools, a new pre-kindergarten program, and school construction.

Residents who have graduated since 1993 from Georgia high schools with at least a 3.0 grade point average are eligible for HOPE. ${ }^{15}$ The first scholarships were disbursed in the fall of 1993.

Participation in HOPE during its first year was limited to those with family incomes below $\$ 66,000$; the

\footnotetext{
${ }^{15}$ The high school GPA requirement is waived for those enrolled in certificate programs at technical institutes. For high school seniors graduating after 2000, only courses in English, math, social studies, science and foreign languages will count toward the GPA requirement. More than 40 percent of those who currently receive the HOPE Scholarship would be ineligible under this definition.
} 
income cap was raised to $\$ 100,000$ in 1994 and eliminated in 1995. HOPE pays for tuition and required fees at Georgia's public colleges and universities. Those attending private colleges are eligible for an annual grant, which was $\$ 500$ in 1993 and had increased to $\$ 3,000$ by 1996 . These amounts are offset by other sources of aid. A student who receives the maximum Pell Grant gets no HOPE Scholarship but receives a yearly book allowance of $\$ 400 .{ }^{16} \mathrm{~A} \$ 500$ education voucher is available to those who complete a General Education Diploma (GED). Public college students must maintain a GPA of 3.0 to keep the scholarship; a similar requirement was introduced for private school students in 1996.

Georgia education officials, concerned that students would forgo applying for federal aid once the HOPE Scholarship was available, created an application process designed to prevent this outcome. Those from families with adjusted gross incomes lower than $\$ 50,000$ must complete the Free Application for Federal Student Aid (FAFSA) in order to apply for HOPE; the rationale for the $\$ 50,000$ income threshold is that few students above that cutoff are eligible for need-based federal aid. ${ }^{17}$ The four-page FAFSA requests detailed income, expense, asset and tax data from the family. Those with family incomes above $\$ 50,000$ fill out a short, one-page form that requires no information about finances other than a confirmation that family income is indeed above the cutoff.

In 1998-99, 140,000 students received \$189 million in HOPE Scholarships. Fifty-four percent of those students attended a two- or four-year college, while the balance attended a technical institute. The bulk of spending (81 percent) goes to the minority of students at two- and four-year schools, however,

\footnotetext{
${ }^{16}$ As a result of this provision and the scaling back of the state's need-based State Student Incentive Grants (SSIGs), some low-income students have actually seen their state aid reduced slightly since HOPE was introduced (Jaffe, 1997). This contemporaneous shift in SSIG spending has the potential to contaminate the paper's estimates, especially the specifications in which low-income youth are used as a control group for upper-income youth. However, SSIG spending was so miniscule - \$5.2 million in 1995, before the program was scaled back - that the impact of its elimination on the estimates is likely inconsequential.

${ }^{17}$ In 1995 , only 3.7 percent of dependent students from families with incomes over $\$ 40,000$ received federal grant aid, while 57 percent of those from families with income under $\$ 20,000$ did so (National Center for Education Statistics, 1998a).
} 
since their tuitions are substantially higher than those of the technical institutes. Georgia politicians have deemed HOPE a great success, pointing to the steady rise in the number of college students receiving HOPE. The key question is whether the program is actually increasing college attendance or simply subsidizing students who would have attended college even in the absence of HOPE. In the next sections, I discuss the data and empirical strategy I will use to answer this question.

\section{Data and Empirical Methodology}

\section{Data}

The data for the analysis are the October Current Population Survey (CPS) and the Integrated Postsecondary Education Data System (IPEDS). The CPS is a monthly, national household survey that each October gathers detailed information about schooling enrollment. IPEDS integrates into a single data set information from a variety of surveys of post-secondary institutions conducted by the US Department of Education.

The CPS will be used for the bulk of the analysis, as its detailed demographic data allow for the identification of youth who are most likely eligible for HOPE. I have merged annual, state-level unemployment statistics from the Bureau of Labor Statistics with the CPS data. Means for the CPS dataset are in Table 1.

The CPS, while the best available resource for the purposes of this paper, has its flaws. First, state samples are small: for the period 1989 to 1997, there are a total of 470 18- to-19-year-olds from Georgia in the October CPS. As a result, year-to-year changes in enrollment rates within Georgia are fairly noisy. ${ }^{18}$ The CPS's small within-state samples also preclude any informative analysis of detailed schooling choices, such as whether college students are induced by HOPE to attend public vs. private schools, or four-year vs. two-year schools. The IPEDS allows for limited exploration of these questions.

\footnotetext{
${ }^{18}$ I could more than double the sample by extending the age cutoff to 22 . However, as was discussed earlier, older youth were not eligible for HOPE during its early years. In fact, later in the paper, older youth will be used as a control group to study the response of younger Georgia residents to HOPE.
} 
Second, information about a youth's family background is not consistently available in the CPS. Family background variables, such as parental income, are available only for those youth that appear on their parents' CPS record. A youth appears on her family's record for one of two reasons: she lives with her family or she is away at college. The probability that a youth has family background information available is therefore a function of her propensity to attend college. This form of sample selection will produce bias in analyses where college attendance is an outcome of interest. ${ }^{19}$ One of the estimation strategies I test requires family income information, and for that analysis the sample is limited to those who appear on their parents' record. I will explore the sensitivity of these results to sample selection. The bulk of the analysis is based on the full sample of 18- to 19- year-olds and is not subject to this source of bias.

Third, the CPS identifies neither the state in which a person attended high school nor the state in which she attends college. A reasonable assumption is that 18- to 19-year-olds attended high school in the state in which they currently reside. Within a group this young, migration across state lines other than to attend college is minimal. And when a youth does go out of state to college, CPS coding standards are that she is recorded as a resident of her home state. ${ }^{20}$ Since the CPS does not provide the state in which the student attends college, I am unable to use these data to detect if HOPE has altered not just the rate of attendance but the proclivity of youth to attend college in-state. The IPEDS allows us to gain some insight into this issue, as the Department of Education every other year gathers from colleges data about their students' states of residence.

\footnotetext{
${ }^{19}$ Cameron and Heckman (1999) discuss this point.

${ }^{20}$ Such youth enter the sample if their parents' home has been selected as a CPS household. Youth who leave home and set up independent households do not show up on their parents' record and are recorded as residents of whatever state they live in. The overwhelming majority (about 90 percent) of 18- to 19year-olds do show up on their parents' record, so these coding rules appear to hold in practice.
} 


\section{Empirical Methodology}

The empirical approach of the paper is straightforward. I examine changes in college attendance rates over time within Georgia, looking for discontinuities at the time of the HOPE's introduction. A control group is required in order to net out any secular trends in college attendance. A natural control group is the other states of the southeastern United States. I use as a control group the South Atlantic and East South Central Census Divisions, which consist of Georgia plus Alabama, Delaware, the District of Columbia, Florida, Kentucky, Maryland, Mississippi, North Carolina, South Carolina, Tennessee, Virginia and West Virginia. As will be shown below, the results are robust to the choice of control group.

The effect of HOPE is identified by differences between Georgia and the rest of the southeastern United States in the time pattern of college attendance rates. I use difference-in-differences estimation, comparing attendance rates before and after HOPE was introduced, within Georgia and in the rest of the region. This calculation can be made using ordinary least squares:

$$
\text { (7) } y_{i}=\alpha_{1}+\beta_{1}\left(\text { Georgia }_{i} * \text { After }_{i}\right)+\delta_{1} \text { Georgia }_{i}+\theta_{1} \text { After }_{i}+v_{i 1}
$$

where the dependent variable is a binary measure of college attendance, Georgia ${ }_{i}$ is a binary variable that is set to one if a youth is a Georgia resident and After $r_{i}$ is a binary variable that is set to one in the sample years in which HOPE was in place (1993 forward). This specification controls for the time trend in college attendance $\left(\boldsymbol{\theta}_{1}\right)$, as well as for the average effect on attendance of being a Georgia resident $\left(\delta_{1}\right)$. The reduced-form effect of the HOPE Scholarship is identified by $\beta_{1}$. The identifying assumption is that any relative shift in the attendance rate of Georgia youth is attributable to the introduction of HOPE. 
I also undertake a strategy that uses within-state control groups. This triple-differencing approach exploits key institutional aspects of HOPE. I first take advantage of the fact that HOPE was initially open to only the youngest high school graduates. In September of 1993, for example, the only HOPE recipients were members of the high school class of 1993. Older youth therefore form a natural control group against which to measure the effect of HOPE on more recent high school graduates. I pool the sample of older (23 to 24$)$ and younger (18 to 19$)$ college-age youth and run the following regression:

$$
\begin{gathered}
y_{i}=\alpha_{2}+\beta_{2}\left(\text { Georgia }_{i} * \text { After }_{i}\right)+\delta_{2} \text { Georgia }_{i}+\boldsymbol{\theta}_{2} \text { After }_{i}+\phi\left(\text { Georgia }_{i} * \text { After }_{i} * \text { Young }_{i}\right) \\
+\eta\left(\text { Georgia }_{i} * \text { Young }_{i}\right)+\lambda\left(\text { After }_{i} * \text { Young }_{i}\right)+\pi \text { Young }_{i}+\mathrm{v}_{i 2}
\end{gathered}
$$

In this equation, Young ${ }_{i}$ is a dummy that indicates whether a person is aged 18 to 19. This specification controls for the main effects of being a Georgia resident $\left(\boldsymbol{\delta}_{2}\right)$ and being aged 18 to $19(\pi)$ as well as their interaction $(\eta)$. The specification further nets out national trends in the college attendance of 18 - to 19-year-olds $(\lambda)$ and shocks to the schooling decisions of Georgia's college-age population $\left(\beta_{2}\right)$. The coefficient of interest is $(\phi)$, which identifies the effect of the HOPE Scholarship on the college attendance rate of 18- to 19-year-olds. This approach has a key advantage over the difference-indifferences of Equation (7) in that the estimated effect of HOPE will not be biased by any Georgiaspecific shocks to the college attendance decisions of young people that occurred after HOPE was introduced.

A second triple-differencing strategy takes advantage of HOPE's family income eligibility rules. As was explained earlier, recent Georgia high school graduates with annual family incomes over $\$ 50,000$ who meet the high school grade requirement automatically qualify for HOPE by filling out a simple, onepage form. Those with lower income, by contrast, apply for federal aid with a complex, four-page form and wait several months to learn the size of their grant award, which is then deducted from their HOPE Scholarship. As a result, lower-income students receive HOPE Scholarships that are both smaller and more uncertain than those received by their better-off peers. We would therefore expect that the 
introduction of the HOPE program had a smaller impact on lower-income youth than higher-income youth.

In order to exploit this aspect of HOPE, I divide the sample into those with annual family incomes above and below $\$ 50,000$. I then run the same triple-difference specification as that of Equation (8) with the variable Young $_{i}$ replaced by a dummy indicating that a youth is from an upper-income family. ${ }^{21}$ This specification identifies the effect of HOPE as the change in the college attendance rate of upper-income over lower-income youth in Georgia relative to the same change in the control states. This approach has the advantage of controlling for any Georgia-specific shock that affects equally the college attendance decisions of upper-income and lower-income youth. But this approach is imperfect, as it is unable to distinguish between two key reasons why HOPE's impact may differ by income: the income eligibility rules described above and differences in academic performance in high school. If lower-income youth perform worse in higher school, then, even if they are offered the same HOPE Scholarship as upper-income youth, they will respond less, since fewer will be able to get into and succeed in college. Evidence indicates that there is a correlation between socioeconomic status (SES) and high school performance. Among high school seniors in 1992 who intended to go to college, 24.4 percent of those of high SES had a grade point average of at least 3.5, while just 10.0 percent of those from low SES families had grades that high. ${ }^{22}$

All estimates are undertaken using ordinary least squares. Probit produces similar results. The CPS sample weights are used in all the regressions. The standard errors are adjusted for heteroskedasticity due to the binary dependent variable. Standard errors are also adjusted for correlation within state and year.

\footnotetext{
${ }^{21}$ The use of family income data in the Current Population Survey in this context potentially produces biased estimates. I discuss this point below.

${ }^{22}$ National Center for Education Statistics (1995).
} 


\section{Results}

\section{Difference-in-Differences Estimates}

Table 2 shows college attendance rates for youth that are residents of Georgia and the rest of the Southeast, before and after the Georgia HOPE Scholarship was introduced in 1993. Previous to the introduction of HOPE, the enrollment rate in Georgia of 18- to 19-year-olds was relatively low: 30.0 percent, as compared to 41.5 percent in the rest of the Southeast. After HOPE was introduced, the enrollment rate in the rest of the Southeast did not change appreciably. However, the Georgia enrollment rate rose to 37.8 percent.

These two differences are differenced in the last column of Table 2. The implied effect of HOPE on the college enrollment rate is 7.9 percentage points. In Table 3, I make the same calculation using ordinary least squares. In the first row of Column (1) is the estimate that corresponds to that of Table $2 .^{23}$ The estimate of 7.9 percent is significant at the one-percent level. This is a fairly large effect, given an initial attendance rate in Georgia of 30 percent. The result implies that HOPE increased attendance probabilities by about 25 percent ( 7.9 percentage points/30 percentage points). Further, the estimates suggest that HOPE nearly closed the gap between Georgia and the rest of the Southeast in college attendance. Later, I will put this effect in perspective by comparing it to previous estimates of the response of college attendance to subsidies.

In the second column of Table 3, I add a set of covariates to the regression. For reasons discussed earlier, I limit myself to covariates that are available for the entire sample. Variables whose generation requires that the youth and parents appear on the same record, such as parental income and education, are not included. I include indicator variables for residence in a metro area, being black, survey year and age.

\footnotetext{
${ }^{23}$ The two estimates are necessarily the same, since it is computationally equivalent to take differences in the means in Table 1 and to regress attendance against the Georgia dummy, the after dummy and their interaction.
} 
The estimate drops slightly, from 7.9 percentage points to 7.5 percentage points, with a standard error of 3.0 percentage points. The estimate is significant at the two-percent level.

I next test whether the estimate is sensitive to the choice of control states. In Table 4, I run the difference-in-difference regression using as control states, in turn, the entire Southeast, the states that border Georgia, and the entire United States. The border-state estimate is 8.7 percentage points, as compared to 7.9 percentage points for the southeastern states. The estimate is significant at the onepercent level. In Column (3), where the control group is the entire United States, the coefficient drops to 7.0 percentage points but is still significant at the one-percent level. The estimates are therefore relatively stable across choice of control group, ranging from 7.0 percentage points to 8.7 percentage points. None of the estimates is more than a standard error away from the other two. Since the results of the paper are consistent across control group, in the remainder of the paper I will only show results that use the southeastern states as the control group.

\section{Controlling for Georgia-Specific Economic Shocks}

Georgia may have experienced economic shocks around the time of HOPE's introduction that were not shared with its neighboring states. In this case, the college attendance rate in Georgia may have diverged from that of its neighbors for reasons unrelated to the introduction of HOPE. I attempt to address this problem in two ways. First, in Column (3) of Table 3, I add to the difference-in-differences regression the unemployment rate in the youth's state of residence during the survey year. The coefficient on the unemployment rate is insignificant and positive. The coefficient of interest is unaffected, however: the difference-in-differences estimate is 7.0 percentage points and is significant at the three-percent level. ${ }^{24}$

An alternative, non-parametric method of controlling for Georgia-specific economic shocks is to use a within-state control group. Youth in their early twenties are likely to experience the same shocks to

\footnotetext{
${ }^{24}$ I have also experimented with specifications that include lags of the unemployment rate. The results are substantively unchanged.
} 
the opportunity costs of college as youth in their late teens. The HOPE Scholarship differentially affects these two groups, however. HOPE eligibility is based on graduating from a Georgia high school in 1993 or later. Even in 1997, those who are aged 23 to 24 would have graduated from high school before HOPE was introduced, and so were generally not eligible for the program. It should be noted that changes in the program rules in 1995 did open HOPE to older Georgians who had completed two years of college with a 3.0 average. But since this older group has never been eligible for subsidies in their first two years of college, they still form a valid control group when the outcome is attendance at the freshman and sophomore level. ${ }^{25}$

Results for this analysis are in Table 5. In the first two columns are separate estimates for the younger, eligible group and the older, ineligible group. The impact of HOPE on freshman and sophomore enrollment among 18- to 19-year-olds is similar to its effect on enrollment at any level of college: 8.1 percentage points, with a standard error of 3.0 percentage points. Among older students, who should be unaffected by HOPE, the effect is zero: 0.7 percentage points with a standard error of 1.1 percentage points. In Column (3), I pool the two age groups into a single regression and test for the statistical significance of the difference between these two coefficients. In Georgia, 18- to 19-year-olds increased their attendance relative to 23 - to 24 -year-olds by 7.5 percentage points more than they did in the other southeastern states. This triple-difference estimate is significant at the three-percent level. If the identifying assumption of the analysis is correct, then this result suggests that the impact of HOPE eligibility was to increase the college attendance rate by 7.5 percentage points.

These last results effectively control for any trends in employment opportunity and college costs (e.g., tuition prices) that affect both the younger and older members of the college-age population. The estimate obtained from this specification is statistically the same as that obtained from the simplest

\footnotetext{
${ }^{25}$ The prospect of receiving HOPE in the third year could, however, affect the probability that an older student enters college. This will tend to bias toward zero my estimate of HOPE's effect when older students are used as the control group.
} 
difference-in-differences analysis in Table 3. The conclusion that HOPE increased college attendance of Georgia's young people by about seven to eight percentage points is therefore robust to a variety of specifications and control groups.

\section{Using Income Data to Identify the Eligible Population}

As was discussed earlier, the eligibility requirements for Georgia's HOPE Scholarship vary by income. The analysis so far has measured increases in relative attendance among all Georgia youth. In order to attempt to narrow in on the group that was most likely eligible for the subsidy, I draw on family income data. Georgia uses $\$ 50,000$ as the income threshold above which students are automatically eligible for the HOPE Scholarship, as long as they meet the high school academic requirements. In Column (1) and Column (2) of Table 6 are regression results for sample members from families with annual incomes above and below $\$ 50,000$, respectively. Among those from higher-income families, the difference-in-differences estimate is 11.4 percentage points, with a standard error of 5.4 percentage points. By contrast, the estimate for lower-income students is -1.4 percentage points and is not statistically different from zero. In Column (3) of Table 5, I pool the two income groups and test whether the difference in their responses to HOPE is statistically significant. A full set of main effects for Georgia residence, income, and time is included in the regression, along with their second-order interactions. The triple interaction of Georgia residence, being of low income and time identifies the effect of the HOPE scholarship in this regression. The difference in response across income groups is significant at the fivepercent level. These results indicate that, in Georgia, higher-income youth increased their attendance relative to lower-income youth by 12.7 percentage points more than they did in the other southeastern states. $^{26}$

${ }^{26}$ Adding a set of covariates (race, urbanicity, and age) to the specifications of Table 5 does not affect the estimates, although their precision is increased slightly. 
Since the group of youth for whom family income is available is a function of the college attendance rate, it is prudent to check the sensitivity of these results to sample selection. In Column (4) of Table 6 is replicated from the previous section the difference-in-differences estimate for the full sample of 18- to 19-year-olds: 7.9 percentage points. In Column (5) I run the same regression with only the 70 percent of 18- to 19-year-olds that appear on their parents' record and have family income data available. The sub-sample estimate of 4.5 percentage points is statistically different from the full-sample estimate, suggesting that selection bias is a problem in this context. Further, as expected, the bias is toward zero.

Note that, in this context, selection bias in the CPS is likely most severe among low-income youth. If the college attendance of low-income youth is particularly sensitive to college costs, then the rate at which they appear on their parents' records will also co-vary particularly strongly with college costs. Selection bias, which will bias downward the estimated effect of a subsidy on college attendance, will then be most severe for low-income students. This suggests that some of the difference in attendance response across income groups found in Table 6 is driven by differing degrees of bias in the estimated coefficients. However, the bias would have to be extremely large in order to negate the conclusion that HOPE has increased the college attendance of upper-income youth more than that of lower-income youth.

\section{The Differential Impact of HOPE on Blacks and Whites in Georgia}

Given the focus of the Georgia HOPE Scholarship on middle- and upper-income families, it is probable that the program has had a differential impact on the college attendance of blacks and whites. To get a sense of the correlation between race and the income guidelines of the Georgia HOPE Scholarship, I examined the family incomes of 16 - to 17 -year-olds in the $1989-1997$ October CPS. ${ }^{27}$ In Georgia during 1989 to 1997, 94 percent of black and 62 percent of white 16- to 17-year-olds lived in families with incomes less than $\$ 50,000 .{ }^{28}$ The numbers for the rest of the United States are similar: 88 and 64 percent,

\footnotetext{
${ }^{27}$ I choose youth of this age because almost all (92 percent) show up in the same record as their parents.

${ }^{28}$ Note that this refers to the nominal income distribution. This is appropriate, since the Georgia rules are written in nominal rather than real terms.
} 
respectively. ${ }^{29}$ These figures indicate than very few black youth in Georgia can, given adequate high school academic performance, automatically qualify for a HOPE Scholarship, while about 40 percent of white youth can. While race is therefore only a rough proxy for income, an analysis by race does skirt the selection bias problems seen in the previous table.

In Table 7, I show the results of splitting the difference-in-differences analysis by race; the estimates for the entire sample are in the first column for ease of comparison. In Column (2) are the estimates for whites. College attendance among whites rose 12.3 percentage points faster over this period in Georgia than in the rest of the southeastern United States. The estimate is significant at the one-percent level. By contrast, college attendance among blacks did not rise significantly in Georgia relative to the other southeastern states: the difference-in-differences estimate for blacks is -2.7 percentage points, with a standard error of 5.2 percentage points. In Column (5) I pool blacks and whites and test for a statistically significant difference in their responses to HOPE. The responses of whites and blacks are different at the six- percent level of statistical significance.

The evidence presented here clearly suggests that HOPE has widened the racial gap in college attendance in Georgia. This is likely due both to HOPE's differential impact by income and its high school academic requirements. Since blacks have lower incomes, they both face a more complicated HOPE application process and are eligible for more generous federal grants, which are deducted from the HOPE Scholarship. And blacks have lower average grades in high school, which means a smaller proportion will meet HOPE's academic requirements: among those members of the high school class of 1992 intending to go to college, 21 percent of whites had a high school GPA of 3.5 or above, while only

\footnotetext{
${ }^{29}$ These figures for the share with income below $\$ 50,000$ may appear high. This is because the unit of observation is not the family but the child. Since lower-income families have more children, the distribution of family income within a sample of children has a lower mean than the distribution of family income within a sample of families.
} 
four percent of blacks had such high grades. ${ }^{30}$ The available data do not allow us to disentangle whether it is the income or academic rules that drive the differential effect of HOPE by on blacks and whites.

\section{Is the Timing Right?}

The results so far suggest that HOPE has had a significant impact on college attendance rates in Georgia. This section probes the robustness of this result by examining more closely the timing of the relative rise in Georgia's attendance rate. A sharp relative increase in attendance rates in Georgia in the years after 1993 is consistent with the hypothesis that HOPE induced the increase in college-going that difference-in-differences has picked up. By contrast, a slow relative rise in Georgia's attendance rates that begins before HOPE was introduced suggests that HOPE is not responsible for this increased attendance. It should be said at the outset that the small size of the year-state cells in the CPS sample makes this a suggestive exercise, as it is quite difficult to differentiate within-state changes in attendance rates that are due to a program change and those that are due to random noise.

In Figure 1, I graph the coefficients from a specification in which college attendance is regressed on the interaction of year dummies and the Georgia dummy, along with state unemployment rate and dummies for age, year, urbanicity and race. The 1992 interaction has been normalized to zero. The 95 percent confidence interval for each point estimate is also plotted. This is equivalent to the difference-indifferences specification in Column (3) of Table (3), except that the Georgia effect is now allowed to vary by year.

In this graph, we can clearly see the relative rise in attendance rates in Georgia that we have picked up with the difference-in-differences regressions. The timing of this rise is less clear. There is a sharp relative increase in 1992, the year before HOPE was introduced. The relative attendance rate rises again in 1994 and 1995 and then especially sharply in 1996. A sharp drop in 1997 sends Georgia's relative attendance rate back to its pre-HOPE level. As will be discussed later, this drop-off in the

\footnotetext{
${ }^{30}$ National Center for Education Statistics (1995).
} 
program's effect may be due to the fact that a majority of freshman HOPE recipients do not receive the HOPE Scholarship in their sophomore year, because they drop out of school and/or fail to meet the college GPA requirement.

Figure 1 does not provide strong support for the hypothesis that HOPE caused the relative rise in Georgia's attendance rate. An alternative explanation is that, for some reason, an upward trend in relative attendance rates in Georgia began in 1992 and simply persisted when HOPE was put in place. We can attempt to distinguish between these competing hypotheses by focusing on the attendance rates of those most likely eligible for HOPE. Figure 2 replicates the previous figure, except that the sample is now limited to those from families with incomes more than $\$ 50,000$. For this group, the time pattern of relative attendance rates is roughly consistent with the timing of HOPE. Relative attendance rates are flat through 1993, the first year of the program. This is to be expected, since in 1993 the family income cap on participation was $\$ 66,000$, thereby excluding from HOPE much of the population whose relative attendance rates are shown in this figure. There is, however, a large relative increase in this group's attendance rate in 1994 , the year that the income cap was raised to $\$ 100,000$. There is another slight relative increase in 1995, the year that the income cap was eliminated completely. The interaction term drops back substantially in 1996, to pre-HOPE levels. ${ }^{31}$

\section{The Effect of HOPE on College Choice}

This section briefly examines the effect of HOPE on students' choice of college. High school students are on a variety of margins when making their decisions about college. Some youth are on the margin of attending college at all. The theoretical effect of HOPE on these youth is to push them college, most likely into less-than-two-year or two-year schools. We therefore expect to see an increase in the college attendance rate, which we have documented in the CPS. Other youth may be set on attending a two-year school. HOPE will push some of them toward a four-year college, by driving down its relative

\footnotetext{
${ }^{31}$ I will discuss a possible explanation for this observed drop-off in HOPE's effect in Section VI.
} 
cost. $^{32}$ The net impact of these two effects on the share of college-going youth attending less-than-fouryear schools is ambiguous, as the first effect will increase the number of youth at less-than-four-year schools and the second effect will push students at those same schools into four-year colleges. A last group of youth is set on attending a four-year school, and HOPE will shift some of them toward choosing to attend college within their home state. ${ }^{33}$

Analysis of annual data from the University System of Georgia (USG) and biennial data from the Department of Education's Residence and Migration Survey (a component of IPEDS) yields results that are consistent with these theorized effects. First, evidence suggests that that HOPE has shifted students from two-year colleges into four-year colleges. Figure 3 graphs data from the USG on the share of its students from Georgia that are attending four-year colleges. This share declined through 1992-93, was level for a year and then began to increase during HOPE's second year of operation. This graph suggests that HOPE has had its second theorized effect, that of encouraging those who would have gone to a twoyear college to instead attend a four-year college. In fact, relying on this graph alone, we would conclude that the second effect of HOPE (shifting youth from less-than-four-year into four-year schools) dominates the first (shifting youth from no college to less-than-four-year schools). However, the USG data do not inform us about enrollment in the private sector, especially at less-than-two-year schools. About half of those receiving HOPE Scholarships are enrolled at these schools, which generally do not grant degrees and are run as for-profit enterprises. Data on enrollment at these schools is quite poor: while the IPEDS surveys all degree-granting schools, it only includes a sample of the non-degree schools and the sampling methodology appears to vary from year to year. We therefore cannot directly measure the effect of HOPE on enrollment at these institutions.

\footnotetext{
${ }^{32}$ Two-year colleges are generally cheaper than four-year colleges. The HOPE Scholarship makes them both free.

${ }^{33}$ Students at four-year colleges, as compared to those at two-year schools, are more likely to be on the margin of attending out of state. Nationwide, about 25 percent of four-year college students go to school outside their home state, while only about three percent of two-year college students do so.
} 
Second, data from both the USG and Residence and Migration Survey suggest that HOPE has had the third theorized effect of encouraging Georgia residents who would have attended four-year college out of state to instead stay in Georgia. Data from the Residence and Migration Survey indicate that in 1992 about 5,000 Georgians were freshmen at two- and four-year colleges in the states that border Georgia. This represented an average of 3.4 percent of the border states' freshmen enrollment. By 1998, just 4,500 Georgians crossed state lines to enter college in the border states, accounting for an average of 2.9 percent of freshmen enrollment in those states. This drop in migration was concentrated in a group of border schools that have traditionally drawn large numbers of Georgians. At the ten schools drawing the most Georgia freshmen in 1992, students from Georgia numbered 1,900 and averaged 17 percent of the freshman class. By 1998, the ten top destinations enrolled 1,700 Georgians, who represented nine percent of freshman enrollment. Jacksonville State College in Florida, for example, drew 189 Georgian freshmen in 1992 and only 89 in 1998; the share of the freshman class from Georgia dropped from 17 to 11 percent.

Further supporting the conclusion that Georgia's four-year college students are now more likely to attend college in state is a shift in the composition of Georgia's four-year colleges. In Figure 4 are graphed data from the USG on the share of freshmen enrollees that are Georgia residents at Georgia's two- and four-year public colleges. The data are separately plotted for the two-year, four-year and the elite four-year colleges in the state. Here we see a definite shift toward Georgia residents since HOPE was introduced, with the effect most pronounced at four-year colleges (especially the top schools) and least evident at the two-year schools. This pattern fits with our understanding that four- year students are most mobile when making college attendance decisions.

\section{Discussion of Results}

The analysis of this section suggests that HOPE increased attendance rates in Georgia. The attendance rate of Georgia's 18 - to 19 -year-olds has risen by 7.0 to 7.9 percentage points relative to that in the rest of the Southeast (Tables 3 and 5). We can convert this result into an estimate comparable to previous studies of the effect of college costs on attendance by dividing the change in attendance by the 
subsidy provided by HOPE. HOPE paid for tuition and mandatory fees at Georgia's public colleges and universities, which averaged $\$ 1900$ from 1993 to $1997 .{ }^{34}$ The estimates of this paper therefore translate into an increase in the attendance rate of 3.7 to 4.2 percentage points for each $\$ 1,000$ in subsidy. How do these estimates compare to previous research on the effect of aid on attendance? Reyes (1995) and Kane (1994) find that a $\$ 1,000$ drop in college costs increases attendance by 1.5 and 3.8 percentage points, respectively. In previous work (Dynarski, 1999), I have estimated that $\$ 1,000$ in grant aid increases attendance of a low- to middle-income population by four percentage points. This places the estimate of HOPE's effect on middle- and upper-income youth at the mid-range of previous estimates of the effect of aid.

In light of the conventional wisdom that middle- and high-income youth are infra-marginal consumers of higher education, this is a surprisingly large effect. There are two possible explanations. First, as was discussed earlier, a larger proportion of upper- than lower-income students may be close to the margin of college attendance. A given subsidy may therefore cause a relatively large share of highincome students to spill over the margin into college. Second, particular characteristics of Georgia and the HOPE Scholarship may intensify the program's effect. This possibility directly affects the validity of the paper's estimates in predicting the effect of other middle-class aid programs. I next turn to a discussion of how confidently we can extrapolate estimates based on the Georgia HOPE Scholarship to programs such as the federal Hope Scholarship.

\footnotetext{
${ }^{34}$ Those attending private colleges are eligible for an annual grant, which was $\$ 500$ in 1993 and gradually increased to $\$ 3,000$ by 1996 . For the $1993-97$ period, $\$ 1,900$ is a fair approximation of HOPE's average subsidy to private college attendance.
} 


\section{What Can the Georgia HOPE Scholarship Tell Us About the Effect of Aid on the Middle Class?}

The paper so far has shown that aid can affect the schooling decisions of middle-income youth. Ideally, we could simply apply the estimates of the paper to a program such as the federal Hope Scholarship. Indeed, there are key similarities between the Georgia and federal programs. They are of roughly equal financial value and focus their subsidies on roughly the same portion of the income distribution. The average value of the Georgia HOPE Scholarship for those attending a public college or university is $\$ 1,900$, while the maximum federal Hope Scholarship is $\$ 1,500$ and the maximum Lifetime Learning Credit is $\$ 1,000 .{ }^{35}$ Both programs largely exclude low-income students by linking the subsidy to how much outside aid is received. ${ }^{36}$ Neither program excludes the well-off: the Georgia program has no income cap on participation while the federal income caps are set quite high in the income distribution.

Despite these similarities, the results of the Georgia analysis should be extrapolated to the federal Hope Scholarship with caution. There are key institutional differences between the Georgia and federal subsidies that will likely drive a wedge between their effects. In the balance of this section, I will discuss these differences, which, as will become clear, generally imply that the impact of the federal Hope Scholarship will be substantially lower than that of the Georgia program.

\section{Information and Transaction Costs of the Georgia and Federal Programs}

It is obvious that a youth, or her family, needs to know about and apply for an aid program if aid eligibility is to affect her schooling decisions. A program that is well-publicized, easily comprehended

\footnotetext{
${ }^{35}$ The Lifetime Learning Credit provides a credit of 20 percent of up to $\$ 5,000$ in tuition, which makes it less valuable than Hope for those attending low-tuition schools. Hope allows a credit equal to the sum of 100 percent of the first $\$ 1,000$ of tuition and 50 percent of the second. The Hope Scholarship is available for just the first two years of college, while the Lifetime Learning Credit is available at any level.

${ }^{36}$ The Georgia program reduces its subsidy one dollar for each dollar of other grant aid. The federal program only allows reimbursement of college costs net of other grant aid. A low-income youth who attends a typical public college and receives an average Pell grant will not get a federal tax credit. By contrast, a middle-class student who attends the typical private school and is not eligible for a Pell grant will get a credit.
} 
and requires little paperwork will have a greater impact on schooling decisions than one that is obscure, complicated and imposes a large burden of paperwork. The latter program has high transaction costs, which reduce the value of aid to an eligible youth. Seeking out information about an aid program, comprehending its rules, and obtaining and completing any necessary forms are all transaction costs that are imposed upon potential students. Transaction costs can also be imposed upon schools, if they are required to handle aid-related paperwork. If schools raise tuition in the face of these increased costs, the impact of a given subsidy will be further reduced.

The transaction costs of the federal program are quite high. The subsidy is delivered through the federal tax code, not known for its transparency or simple paperwork. The size of the subsidy is uncertain when the college-attendance decision is made, since taxpayers do not know the size of their credit until their tax liability and eligible educational expenses for a given year have been determined. ${ }^{37}$ The program is costly to schools, as well, which are required to collect information about who is responsible for a given student's tuition (parents and outside scholarship providers, for example) and mail to the Internal Revenue Service a listing of the responsible parties, their taxpayer identification numbers, and an annual accounting of the portion of tuition and fees eligible for the tax credit. ${ }^{38}$

By contrast, Georgia's program has unusually low transaction costs. Information about the program is effectively disseminated through the high schools. Fifty-nine percent of high school freshmen, when asked to list some requirements of HOPE, volunteer that a high school GPA of 3.0 is necessary; more than seventy percent can name the program without prompting.${ }^{39}$ The paperwork is minimal, at least for students from families with incomes above $\$ 50,000$. The application for the 1998-99 academic

\footnotetext{
${ }^{37}$ The federal credit is therefore delivered well after educational expenses have been incurred. This aspect of the program will likely reduce the its impact among liquidity-constrained families.

${ }^{38}$ Bowing to complaints that the new reporting requirements are expensive and burdensome, the IRS has waived this requirement until after the 2000 tax year (Hebel, 1999b).

${ }^{39}$ Henry et al. (undated).
} 
year for that group consists of a single page with about a dozen questions, of which the only financial query is: “Was your family’s Adjusted Gross Income for 1997 \$50,000 or more?” Lower-income students fill out the a four-page form that is roughly as involved as the typical tax return. In order to ease this process, Georgia college officials assist applicants in completing this form, check it for accuracy, and mail it in.

\section{Tuition Effects of the Georgia and Federal Programs}

Opponents of the federal tax credits have expressed concern that they will drive up tuition prices, as schools seek to capture the subsidy. The California legislature has discussed raising tuitions so that its students can qualify for the full Hope Scholarship. ${ }^{40}$ To gauge whether HOPE has driven up tuition prices in Georgia, I examine trends in schooling costs in Georgia and the US. Plotted in Figure 5 is the natural $\log$ of the average tuition, fees, room and board paid by students at public four-year colleges in Georgia and the rest of the US for the academic years 1986-87 through 1997-98. Figure 6 contains the corresponding graph for private four-year colleges. ${ }^{41}$

Public college costs were relatively flat in Georgia before HOPE, with costs in 1993-94 only about six percent higher than their level in 1986-87. Real prices in Georgia actually dropped during the years immediately preceding HOPE. By contrast, real public schooling costs in the US rose steadily between 1986-87 and 1993-94, for a total increase over this period of around 15 percentage points. After HOPE was introduced, the situation was reversed, with public college costs in Georgia rising at a rate higher than that of the US. Between 1993-94 and 1997- 98, schooling costs rose about 21 percent in

40 Basinger and Healy (1998). A student must incur at least $\$ 2,000$ in eligible costs in order to get the full Hope credit. Many community colleges, and some state universities, charge tuition lower than that threshold.

${ }^{41}$ These data are from Table 312 in National Center for Education Statistics (1998a) and Table 81 in National Center for Education Statistics (1998b). The Georgia series are much noisier than the national series, which is likely a function of their relative sample sizes: a single school's large tuition increase can shift the Georgia mean appreciably, while the actions of a single school are not likely to visibly affect the national trend. 
Georgia and 8 percent in the rest of the US. To a lesser degree, the same pattern emerges from the plot of private school costs in Figure 6. Private schooling costs rose slightly faster in the US than Georgia before HOPE (18 vs. 16 percentage points, respectively) but the situation was reversed after HOPE was introduced ( 8 vs. 12 percentage points, respectively).

These results suggest that HOPE has had an inflationary effect on college costs in Georgia, especially on the public schools. ${ }^{42}$ The inflationary effect of the federal tax credit on tuition is likely to be even stronger. In Georgia, the state government both distributes the subsidy and sets tuition prices for the public sector, which should at least moderate schools' tendency to raise prices in order to capture the subsidy. There is no such brake in the federal program, since the federal government has no control over prices in the higher-education market. We would therefore expect the inflationary effects of the federal scholarship to be more severe. ${ }^{43}$

\section{Academic Requirements of the Georgia Program}

Georgia's subsidy requires a 3.0 GPA in both high school and college; the federal program has no grade requirement. The high school GPA requirement theoretically has two countervailing effects. It could magnify HOPE's effect by encouraging students to increase their academic effort and decrease its effect by denying eligibility to those who are slightly below the grade cutoff but who can handle collegelevel work. The requirement might also encourage grade inflation in high school, which would expand the pool of students that, at least on paper, meet minimum college entry requirements. How this affects the

\footnotetext{
${ }^{42}$ While the dollar value of the HOPE subsidy is roughly the same in private and public sectors, schooling costs are higher in the private schools. We would therefore expect HOPE to induce a smaller percentage increase in private than in public schooling costs, which is consistent with the results seen here. HOPE would also tend to have a smaller level effect on prices in the private than the public sector, since the scholarship covers only a fixed dollar portion of private tuition but all of public tuition, thereby giving public schools more latitude in raising prices.

${ }^{43}$ Further, if the federal Hope Scholarship leads to tuition increases, the net effect of this program may be to decrease black and low-income attendance, since these populations will face the full impact of higher tuition but largely be ineligible for the subsidy. Institutions may choose to ameliorate this effect, however, by using their increased tuition revenues to cross-subsidize needy students who are ineligible for Hope.
} 
number of students HOPE induces to attend college depends on how able colleges are to detect grade inflation.

The effect of the college GPA requirement is less ambiguous. The B-average requirement cuts off financial assistance to students who could make it through college, albeit with mediocre grades, and is therefore almost certain to reduce HOPE's impact on college attendance. Sixty-four percent of freshmen who received HOPE during academic year 1997-98 lost their scholarships the following year. ${ }^{44}$ The $^{-1}$ college GPA requirement therefore culls from HOPE eligibility not just those who can't handle college, but the median college student. Further, the college GPA requirement appears to hit Blacks harder than whites. Blacks at the University of Georgia are twice as likely as whites to lose their scholarship after the freshman year (Healy, 1997). A recent study found that at the Georgia Institute of Technology also found that Blacks were substantially more likely than whites to lose their scholarships, though this differential disappeared after accounting for differences in ability as measured by SAT scores. ${ }^{45}$

The substantial rate of attrition from HOPE may explain a result observed earlier: as seen in Figures 1 and 2, the effect of HOPE on college attendance appears to have dropped in recent years. It is possible that young people on the margin of college attendance have observed the very high rate at which their older peers have lost their HOPE Scholarships and decided that the expectation of one year of free tuition is not enough to make college worthwhile. ${ }^{46}$

\footnotetext{
${ }^{44}$ Data from Steve Thomkins of the Georgia Student Finance Commission.

${ }^{45}$ Dee and Jackson (1999).

${ }^{46}$ It is true that the number of HOPE Scholars has risen steadily over time, which would seem to contradict the finding that its effect on attendance is diminishing. However, HOPE take-up can rise due to two shifts in student behavior that have no impact on the college attendance rate: students who would have gone to college anyway choose to attend in Georgia and students who would have gone to college anyway increase their high school grades marginally so as to meet the HOPE academic requirement.
} 


\section{Other Differences between the Federal and Georgia Programs}

There are two more key differences between the Georgia and federal subsidy programs. The first is the conditions into which these two programs have been introduced. The college attendance rate in Georgia when HOPE was introduced was much lower than that in the rest of the US. A large reservoir of youth not attending college may have contributed to the program's large impact. It is likely that the effect of the federal Hope Scholarship will vary geographically, producing a larger impact in states where attendance is low and a smaller impact where attendance is high.

Second, the federal program is national in scope: a person can use the credit anywhere in the US. By contrast, Georgia requires that a student stay in the state in order to receive the scholarship. However, the vast majority ( 83 percent) of freshmen attends college in their home state. ${ }^{47}$ This figure is likely even higher for youth on the margin of college attendance. As a result, this particular difference between the two programs is most likely inconsequential to their relative impact on college attendance rates.

\section{Predicted Net Impact of the Federal Hope Scholarship}

Most of the differences between the two programs point to the federal Hope Scholarship having a lesser impact on the college attendance of middle- and upper-income youth than has Georgia HOPE. The federal Hope Scholarship delivers its subsidy after tuition has been paid; is administered through the complex US tax code; threatens to push up tuition prices; and is being offered to a US population whose college attendance rates are already substantially higher than those in Georgia. These characteristics combine to reduce the effect of the federal program relative to that of Georgia's. The results therefore provide an upper bound on the impact of the federal Hope Scholarship on recent high school graduates, suggesting that each $\$ 1,000$ in tax credits could increase their college attendance rate by as much as four percentage points.

\footnotetext{
${ }^{47}$ National Center for Education Statistics (1998a), Table 203.
} 
The Georgia experience indicates that any impact of the federal Hope Scholarship on college attendance will come with the price of exacerbating already substantial racial and income gaps in college attendance. In Georgia, the HOPE Scholarship has increased overall college attendance but widened the gap in attendance rates between whites and Blacks and between rich and poor. The results in Table 6 and Table 7 indicate that, since HOPE was introduced, gaps in college attendance between Blacks and whites and between upper- and lower-income youth in Georgia have risen substantially more than they have in the rest of the Southeast. Nationwide, the gap in attendance rates between recent high school graduates in the bottom and top quartiles of the family income distribution is 30 percentage points. Even after controlling for ability, as measured by standardized test scores, this gap remains quite large: among the middle third of test scorers, the gap between high- and low-income youth is 22 percent. Further, differences in college attendance across income groups have been growing over time. ${ }^{48}$ Programs that primarily subsidize the college attendance of middle- and upper-income youth, like the federal Hope Scholarship and Georgia HOPE Scholarship, will only exacerbate this trend.

\section{Conclusion}

The federal government and the states have recently enacted a slew of new student aid programs aimed at youth from middle- and high-income families. There has been little research on the sensitivity to college costs of this group's attendance rates. In this paper, I estimate the impact of aid on the college attendance of middle- and upper-income youth by evaluating the Georgia program that is the namesake and inspiration of the new federal Hope Scholarship: the Georgia HOPE (Helping Outstanding Pupils Educationally) Scholarship. The results suggest that Georgia's program has had a surprisingly large effect on the college attendance rate of middle- and high-income youth. Using a set of nearby states as a

\footnotetext{
${ }^{48}$ The figures on college attendance, family income and test scores are from Ellwood and Kane (1999).
} 
control group, I find that Georgia's program has likely increased the college attendance rate among 18- to 19-year-olds by seven to eight percentage points.

I further find that the program's effect is concentrated among Georgia's white students, who have experienced a 12.3 percentage point rise in their attendance rate relative to whites in comparison states. The black attendance rate in Georgia has not increased relative to that in comparison states since HOPE was introduced. The racial gap in college attendance in Georgia has therefore increased relative to its level in the rest of the Southeast. The evidence also suggests that Georgia's program has widened the gap in college attendance between those from low-income and high-income families. The federal Hope Scholarship, which focuses on the same slice of the family income distribution as Georgia's program, is also likely to exacerbate already large racial and income gaps in college attendance in the US. 


\section{References}

Angrist, Joshua (1993). "The Effect of Veterans Benefits on Education and Earnings.” Industrial and Labor Relations Review 46:4, 637-52.

Basinger, Julianne and Patrick Healy (1998). "Will New Federal Tax Breaks Hurt California's Colleges?” The Chronicle of Higher Education, March 6, p. A36.

Bugler, Daniel and Gary Henry (1997). "Evaluating the Georgia HOPE Scholarship Program: Impact on Students Attending Public Colleges and Universities." Unpublished manuscript, Council for School Performance, Georgia State University.

Bugler, Daniel and Gary Henry (1998). “An Evaluation of Georgia's HOPE Scholarship Program: Impact on College Attendance and Performance." Unpublished manuscript, Council for School Performance, Georgia State University.

Byron, Kris and Gary Henry (1996). "Report on the Expenditure of Lottery Funds Fiscal Year 1996." Unpublished manuscript, Council for School Performance, Georgia State University.

Byron, Kris and Gary Henry (1997). "Report on the Expenditure of Lottery Funds Fiscal Year 1997." Unpublished manuscript, Council for School Performance, Georgia State University.

Byron, Kris and Gary Henry (1998). "Report on the Expenditure of Lottery Funds Fiscal Year 1998." Unpublished manuscript, Council for School Performance, Georgia State University.

Cameron, Stephen and James Heckman (1999). "Can Tuition Policy Combat Rising Wage Inequality?" In Marvin Kosters, ed., Financing College Tuition: Government Politics and Educational Priorities. Washington, D.C.: American Enterprise Institute.

College Board (1998). Trends in Student Aid. New York: College Board Publications.

Cronin, Julie-Anne (1997). “The Economic Effects and Beneficiaries of the Administration's Proposed National Tax Journal50:3, pp. 519-40..

Dee, Thomas and Linda Jackson (1999). "Who Loses Hope? Attrition from Georgia's College Southern Economic Journal 66:2, pp. 379-90.

Dynarski, Susan (1999). "Does Aid Matter? Measuring the Effect of Student Aid on College Attendance and Completion." National Bureau of Economic Research Working Paper No. 7422..

Ellwood, David and Thomas Kane (1999). "Who Is Getting a College Education? Family Background and the Growing Gap in Enrollment." Unpublished manuscript, Harvard University.

Healy, Patrick (1997). "HOPE Scholarships Transform the University of Georgia." The Chronicle of Higher Education, November 7, p. A32. 
Hebel, Sara (1999a). "New Tax Credits Are Changing the Economics of Student Aid." The Chronicle of Higher Education, May 21, p. A31.

(1999b). "IRS Delays Reporting Requirements for Two New Tax Credits for College Costs." The Chronicle of Higher Education, August 6, p. A36.

Henry, Gary and others (undated). "Hope Longitudinal Study, First-Year Results.” Unpublished manuscript, Council for School Performance, Georgia State University.

Hollenbeck, Scott and Maureen Kahn (1998). "Individual Income Tax Returns, 1997: Early Tax Statistics of Income Bulletin 18:3.

Jaffe, Greg (1997). "Free for All: Georgia's Scholarships Are Open to Everyone, and That's a Problem." The Wall Street Journal, June 2, p. 1.

Kane, Thomas (1999a). "Rethinking the Way Americans Pay for College." Milken Institute Review.

Kane, Thomas (1999b). The Price of Admission. Washington, DC: Brookings.

Kane, Thomas (1994). "College Entry by Blacks since 1970: The Role of College Costs, Family Background, and the Returns to Education.” Journal of Political Economy 102:5, 878-911.

Leslie, Larry and Paul Brinkman (1988). The Economic Value of Higher Education. New York: Macmillan.

National Center for Education Statistics, US Department of Education (1995). Making the Cut: Who Meets Highly Selective College Entrance Criteria? Washington, D.C.: Government Printing Office.

(1997). Digest of Education Statistics. Washington, D.C.: Government Printing Office.

(1998a). Digest of Education Statistics. Washington, D.C.: Government Printing Office.

(1998b). State Comparisons of Education Statistics: 1969-70 to 1996-97. Washington, D.C.: Government Printing Office.

Reyes, Suzanne (1995). "Educational Opportunities and Outcomes: The Role of the Guaranteed Student Loan.” Unpublished manuscript, Harvard University.

Selingo, Jeff (1999). “Copying Georgia's HOPE: States That Are Weighing Tuition-Scholarship The Chronicle of Higher Education, April 16, p. A37.

Stanley, Marcus (1999). "College Education and the Mid-Century G.I. Bills." Unpublished manuscript, Harvard University. 
Table 1:

Sample Means

October CPS, 1989-97

18-19-Year-Olds

\begin{tabular}{lcccc}
\hline \hline & \multicolumn{2}{c}{$1989-92$} & \multicolumn{2}{c}{$1993-97$} \\
\hline & Georgia & $\begin{array}{c}\text { Southeastern } \\
\text { States }\end{array}$ & Georgia & $\begin{array}{c}\text { Southeastern } \\
\text { States }\end{array}$ \\
\hline Black & & & & \\
Family Income $<\$ 50 \mathrm{~K}$ & 0.377 & 0.265 & 0.325 & 0.260 \\
Metro Area Resident & $(0.486)$ & $(0.441)$ & $(0.469)$ & $(0.438)$ \\
Age 18 & 0.754 & 0.740 & 0.611 & 0.666 \\
State Unemployment Rate & $(0.432)$ & $(0.439)$ & $(0.489)$ & $(0.472)$ \\
& 0.661 & 0.682 & 0.703 & 0.716 \\
$\mathrm{~N}$ & $(0.475)$ & $(0.467)$ & $(0.458)$ & $(0.451)$ \\
& 0.474 & 0.492 & 0.522 & 0.503 \\
& $(0.500)$ & $(0.500)$ & $(0.500)$ & $(0.500)$ \\
\hline \hline
\end{tabular}

Note: Means are weighted by CPS sample weights. The income mean is for the 70.2 percent of 18 - to 19-year-olds that both appear on their parents' CPS record and have a valid response to the family income question. The Southeastern states consist of the South Atlantic and East South Central Census Divisions: Alabama, Delaware, District of Columbia, Florida, Kentucky, Maryland, Mississippi, North Carolina, South Carolina, Tennessee, Virginia and West Virginia. 
Table 2:

Difference-in-Differences

Share of 18-19-Year-Olds Attending College

October CPS, 1989-97

\begin{tabular}{lccc}
\hline & Before 1993 & 1993 and After & Difference \\
\hline \hline Georgia & 0.300 & 0.378 & 0.078 \\
Rest of Southeastern States & 0.415 & 0.414 & -0.001 \\
Difference & 0.115 & 0.036 & 0.079 \\
& & & \\
\hline
\end{tabular}

Note: Means are weighted by CPS sample weights. The Southeastern states are defined in the note to Table 1. 
Table 3:

College Attendance of 18-19-Year-Olds

October CPS, 1989-97

Control Group: Southeastern States

\begin{tabular}{|c|c|c|c|}
\hline & $\begin{array}{c}(1) \\
\text { Difference-in- } \\
\text { Differences }\end{array}$ & $\begin{array}{c}(2) \\
\text { Add Covariates }\end{array}$ & $\begin{array}{c}(3) \\
\text { Add Local } \\
\text { Economic } \\
\text { Conditions } \\
\text { Controls }\end{array}$ \\
\hline After*Georgia & $\begin{array}{c}0.079 \\
(0.029)\end{array}$ & $\begin{array}{c}0.075 \\
(0.030)\end{array}$ & $\begin{array}{c}0.070 \\
(0.030)\end{array}$ \\
\hline Georgia & $\begin{array}{l}-0.115 \\
(0.023)\end{array}$ & $\begin{array}{l}-0.100 \\
(0.019)\end{array}$ & $\begin{array}{l}-0.097 \\
(0.018)\end{array}$ \\
\hline After & $\begin{array}{l}-0.001 \\
(0.018)\end{array}$ & & \\
\hline Age 18 & & $\begin{array}{l}-0.042 \\
(0.014)\end{array}$ & $\begin{array}{l}-0.042 \\
(0.016)\end{array}$ \\
\hline Metro Resident & & $\begin{array}{c}0.042 \\
(0.016)\end{array}$ & $\begin{array}{c}0.042 \\
(0.015)\end{array}$ \\
\hline Black & & $\begin{array}{l}-0.134 \\
(0.014)\end{array}$ & $\begin{array}{l}-0.133 \\
(0.015)\end{array}$ \\
\hline State Unemployment Rate & & & $\begin{array}{c}0.005 \\
(0.007)\end{array}$ \\
\hline Year Dummies & & Yes & Yes \\
\hline $\mathrm{R}^{2}$ & 0.003 & 0.023 & 0.023 \\
\hline $\mathrm{N}$ & 6,811 & 6,811 & 6,811 \\
\hline
\end{tabular}

Note: Regressions are weighted by CPS sample weights. Standard errors are adjusted for heteroskedasticity and correlation within state-year cells. The Southeastern states are defined in the note to Table 1. 
Table 4:

Alternative Control Groups

College Enrollment of 18-19-Year-Olds

October CPS, 1989-97

\begin{tabular}{lccc}
\hline \hline & & & \\
& $(1)$ & $(2)$ & $(3)$ \\
& Southeastern States & States Bordering Georgia & United States \\
\hline \multirow{2}{*}{ After*Georgia } & 0.079 & 0.087 & 0.070 \\
& $(0.029)$ & $(0.031)$ & $(0.024)$ \\
Georgia & -0.115 & -0.100 & -0.135 \\
& $(0.023)$ & $(0.025)$ & $(0.021)$ \\
After & -0.001 & -0.008 & 0.009 \\
& $(0.018)$ & $(0.021)$ & $(0.009)$ \\
$\mathrm{R}^{2}$ & 0.003 & 0.003 & 0.001 \\
$\mathrm{~N}$ & & & 32,266 \\
\hline \hline
\end{tabular}

Note: Regressions are weighted by CPS sample weights. Standard errors are adjusted for heteroskedasticity and correlation within state-year cells. The states that border Georgia are Alabama, Florida, North Carolina, South Carolina, and Tennessee. The Southeastern states are defined in the note to Table 2. 
Table 5:

Triple Difference, by Age

Freshman and Sophomore College Enrollment

October CPS, 1989-97

Control Group: Southeastern States

(1)

Difference-in-

Differences:

Age Group

Affected by

Scholarship

(18-19)
(2)

Difference-in-

Differences:

Age Group Not

Affected by

Scholarship
(3)

Difference-in-

Differences-in-

Differences

Pooled Regression

After*Georgia*Age 18-19

0.075

(0.034)

After*Georgia

0.081

(0.030)

0.007

0.007

(0.011)

(0.011)

Georgia

$-0.101$

$-0.021$

$-0.021$

(0.023)

(0.010)

(0.010)

After

$-0.016$

(0.018)

0.009

0.009

(0.005)

$(0.005)$

Age 18-19

0.364

(0.012)

Georgia*Age 18-19

$-0.080$

(0.027)

After*Age 18-19

$-0.025$

(0.019)

$\mathrm{R}^{2}$

0.002

0.001

0.185

$\mathrm{N}$

6,811

7,445

14,526

Note: Regressions are weighted by CPS sample weights. Standard errors are adjusted for heteroskedasticity and correlation within state-year cells. The Southeastern states are defined in the note to Table 1 . 
Table 6:

Triple Difference, by Income

College Enrollment of 18-19-Year-Olds

October CPS, 1989-97

Control Group: Southeastern States

(1)

(2)

Parents'

Income

$<\$ 50 \mathrm{~K}$

(3)

(4)

(5)

\begin{tabular}{|c|c|}
\hline Parents' & Parents' \\
\hline $\begin{array}{l}\text { Income } \\
>\$ 50 \mathrm{~K}\end{array}$ & $\begin{array}{l}\text { Income } \\
<\$ 50 \mathrm{~K}\end{array}$ \\
\hline
\end{tabular}

Full Sample Limit to

Those

With Parents'

Income Data

After*Georgia*> \$50K

0.127

(0.062)

\begin{tabular}{|c|c|c|c|c|c|}
\hline After*Georgia & $\begin{array}{c}0.114 \\
(0.054)\end{array}$ & $\begin{array}{l}-0.014 \\
(0.062)\end{array}$ & $\begin{array}{l}-0.014 \\
(0.062)\end{array}$ & $\begin{array}{c}0.079 \\
(0.029)\end{array}$ & $\begin{array}{c}0.045 \\
(0.043)\end{array}$ \\
\hline Georgia & $\begin{array}{c}-0.159 \\
(0.041)\end{array}$ & $\begin{array}{l}-0.067 \\
(0.038)\end{array}$ & $\begin{array}{l}-0.067 \\
(0.038)\end{array}$ & $\begin{array}{l}-0.115 \\
(0.023)\end{array}$ & $\begin{array}{l}-0.095 \\
(0.034)\end{array}$ \\
\hline After & $\begin{array}{c}-0.070 \\
(0.030)\end{array}$ & $\begin{array}{l}-0.037 \\
(0.018)\end{array}$ & $\begin{array}{l}-0.037 \\
(0.018)\end{array}$ & $\begin{array}{c}-0.001 \\
(0.018)\end{array}$ & $\begin{array}{l}-0.022 \\
(0.018)\end{array}$ \\
\hline$>\$ 50 \mathrm{~K}$ & & & $\begin{array}{c}0.350 \\
(0.023)\end{array}$ & & \\
\hline Georgia*> $\$ 50 \mathrm{~K}$ & & & $\begin{array}{l}-0.091 \\
(0.030)\end{array}$ & & \\
\hline After*> $\$ 50 \mathrm{~K}$ & & & $\begin{array}{l}-0.033 \\
(0.035)\end{array}$ & & \\
\hline $\mathrm{R}^{2}$ & 0.009 & 0.004 & 0.094 & 0.003 & 0.002 \\
\hline $\mathrm{N}$ & 1,401 & 3,380 & 4,781 & 6,811 & 4,781 \\
\hline
\end{tabular}

Note: Regressions are weighted by CPS sample weights. Standard errors are adjusted for heteroskedasticity and correlation within state-year cells. The Southeastern states are defined in the note to Table 1. 
Table 7:

Triple Difference, by Race

College Enrollment of 18-19-Year-Olds

October CPS, 1989-97

Control Group: Southeastern States

\begin{tabular}{|c|c|c|c|c|}
\hline & $\begin{array}{c}(1) \\
\text { Full Sample }\end{array}$ & $\begin{array}{c}\text { (2) } \\
\text { Whites }\end{array}$ & $\begin{array}{c}(3) \\
\text { Blacks }\end{array}$ & $\begin{array}{c}(4) \\
\text { Triple } \\
\text { Difference }\end{array}$ \\
\hline After*Georgia*White & & & & $\begin{array}{c}0.149 \\
(0.079)\end{array}$ \\
\hline After*Georgia & $\begin{array}{c}0.079 \\
(0.029)\end{array}$ & $\begin{array}{c}0.123 \\
(0.045)\end{array}$ & $\begin{array}{l}-0.027 \\
(0.052)\end{array}$ & $\begin{array}{l}-0.027 \\
(0.052)\end{array}$ \\
\hline Georgia & $\begin{array}{l}-0.115 \\
(0.023)\end{array}$ & $\begin{array}{l}-0.109 \\
(0.039)\end{array}$ & $\begin{array}{l}-0.088 \\
(0.030)\end{array}$ & $\begin{array}{l}-0.088 \\
(0.030)\end{array}$ \\
\hline After & $\begin{array}{l}-0.001 \\
(0.018)\end{array}$ & $\begin{array}{l}-0.002 \\
(0.022)\end{array}$ & $\begin{array}{l}-0.000 \\
(0.026)\end{array}$ & $\begin{array}{l}-0.000 \\
(0.026)\end{array}$ \\
\hline White & & & & $\begin{array}{c}0.126 \\
(0.021)\end{array}$ \\
\hline Georgia*White & & & & $\begin{array}{l}-0.020 \\
(0.058)\end{array}$ \\
\hline After* $>$ White & & & & $\begin{array}{l}-0.001 \\
(0.030)\end{array}$ \\
\hline $\mathrm{R}^{2}$ & 0.003 & 0.002 & 0.007 & 0.019 \\
\hline $\mathrm{N}$ & 6,811 & 4,974 & 1,837 & 6,811 \\
\hline
\end{tabular}

Note: Regressions are weighted by CPS sample weights. Standard errors are adjusted for heteroskedasticity and correlation within state-year cells. The Southeastern states are defined in the note to Table 1. 

Figure 1:

Estimated Effect of HOPE Eligibility on College Attendance, By Year

1992 Normalized to Zero

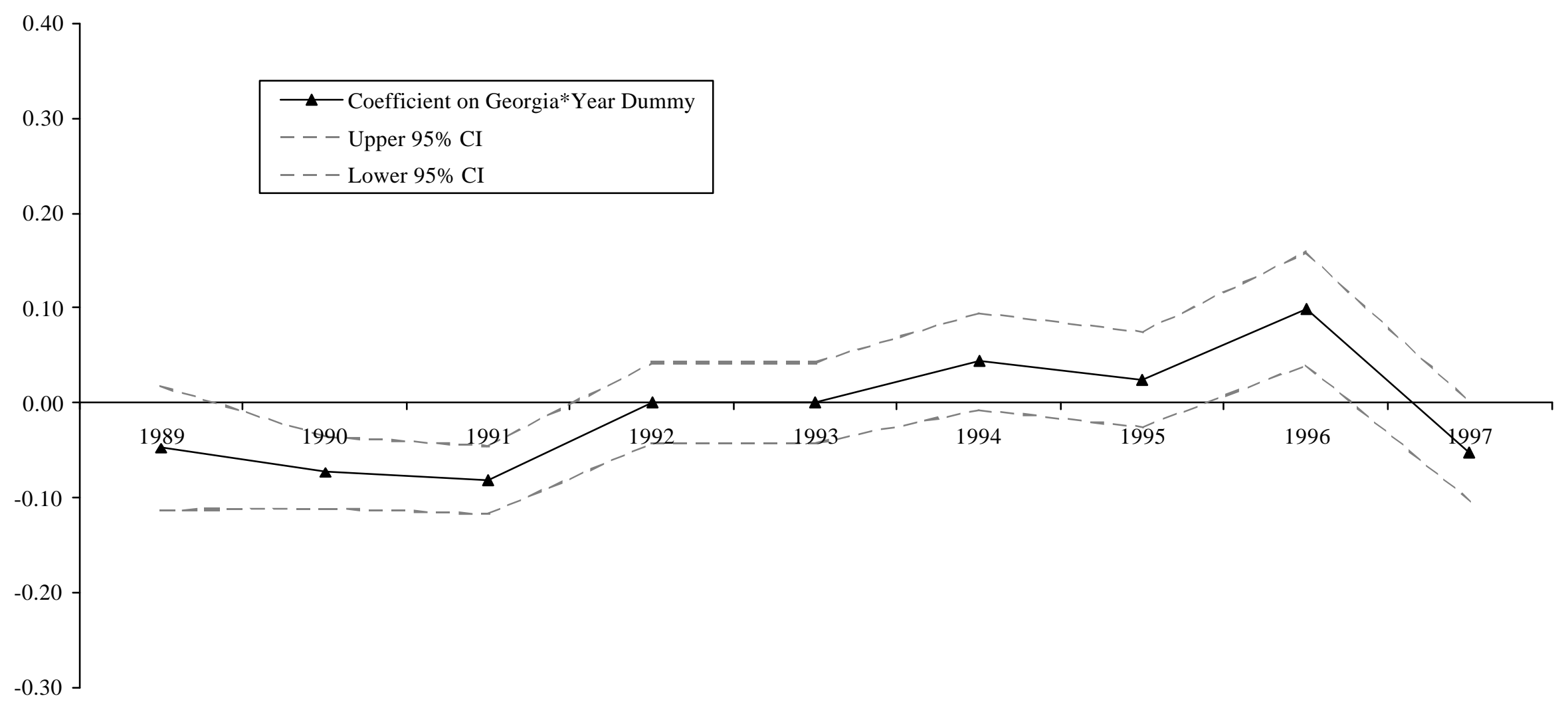

Graphed are the coefficients on the interaction of year dummies with the Georgia dummy. Coefficients are obtained from a single regression that includes the Georgia*year interactions as well as the state unemployment rate and dummies for year, age, race and urbanicity. Dependent variable is an indicator for college attendance. 
Figure 2: Family Income $>\$ 50 \mathrm{~K}$

Estimated Effect of HOPE Eligibility on College Attendance, By Year

1992 Normalized to Zero

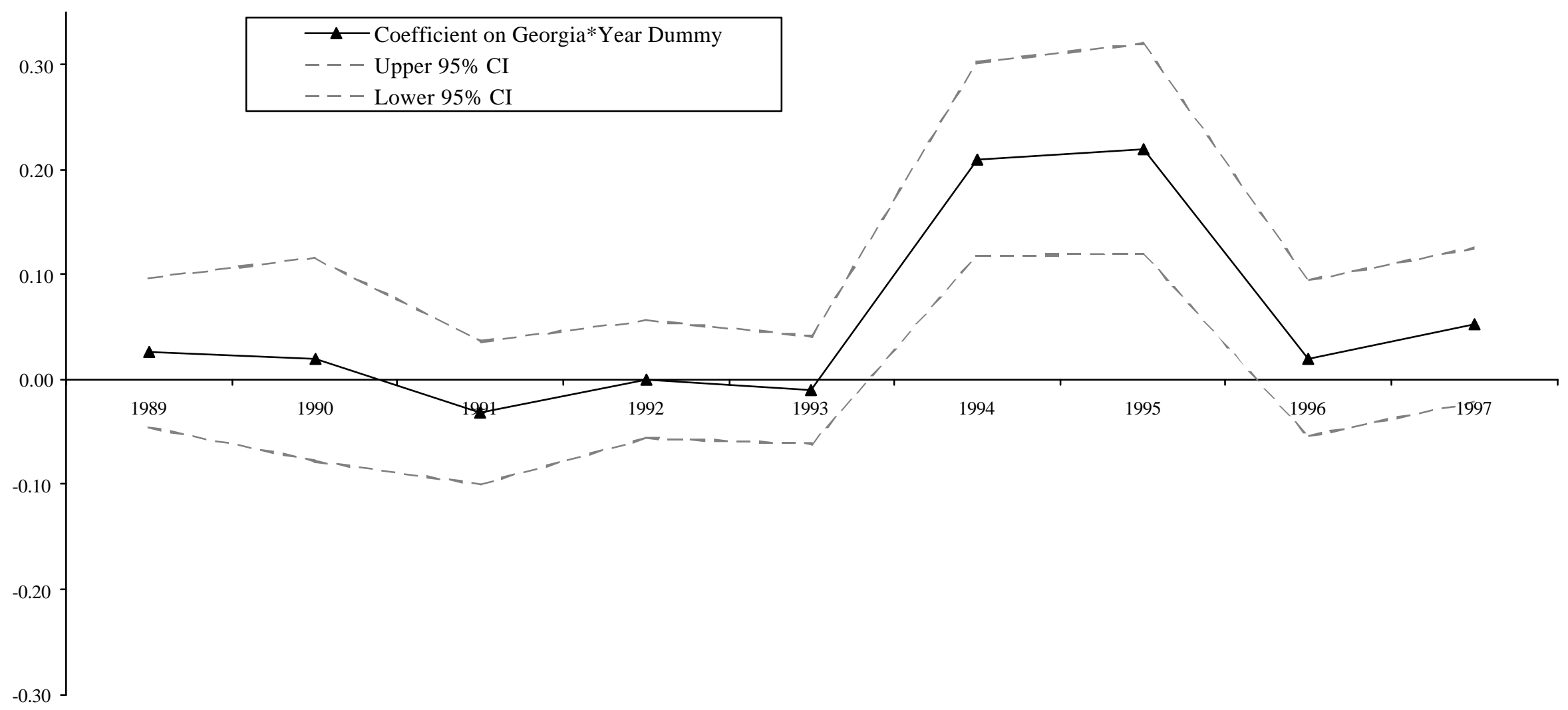

Graphed are the coefficients on the interaction of year dummies with the Georgia dummy. Coefficients are obtained from a single regression that includes the Georgia*year interactions as well as the state unemployment rate and dummies for year, age, race and urbanicity. Dependent variable is an indicator for college attendance. 
Figure 3:

University System of Georgia Students

Share of Georgia Residents Enrolled in Four-Year Colleges

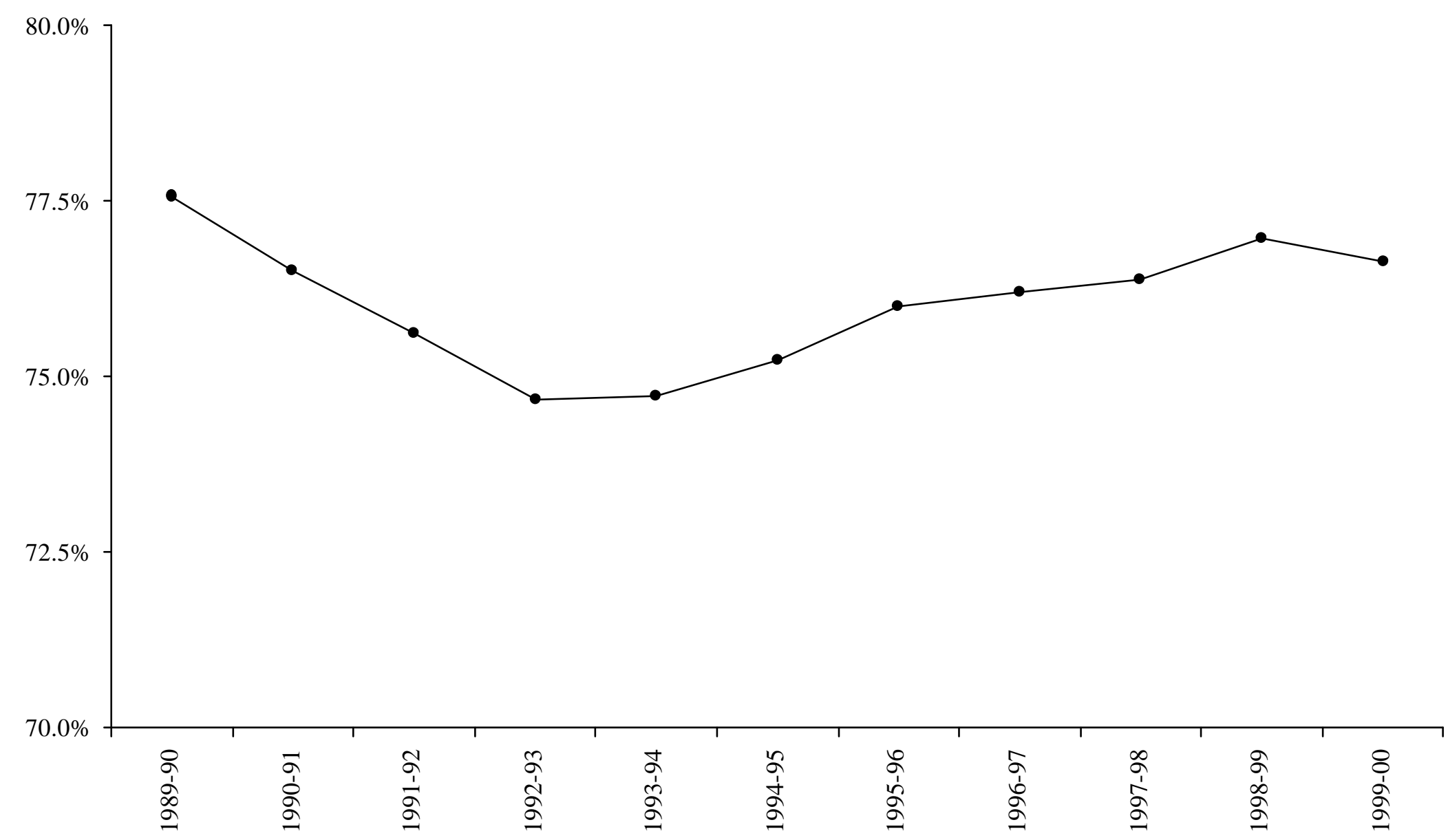

Graphed is the share of USG students from Georgia who are enrolled in four-year colleges. Source: University System of Georgia Ten-Year Enrollment Report, various years. 
Figure 4:

University System of Georgia Students

Georgia Residents as Share of Total Enrollment

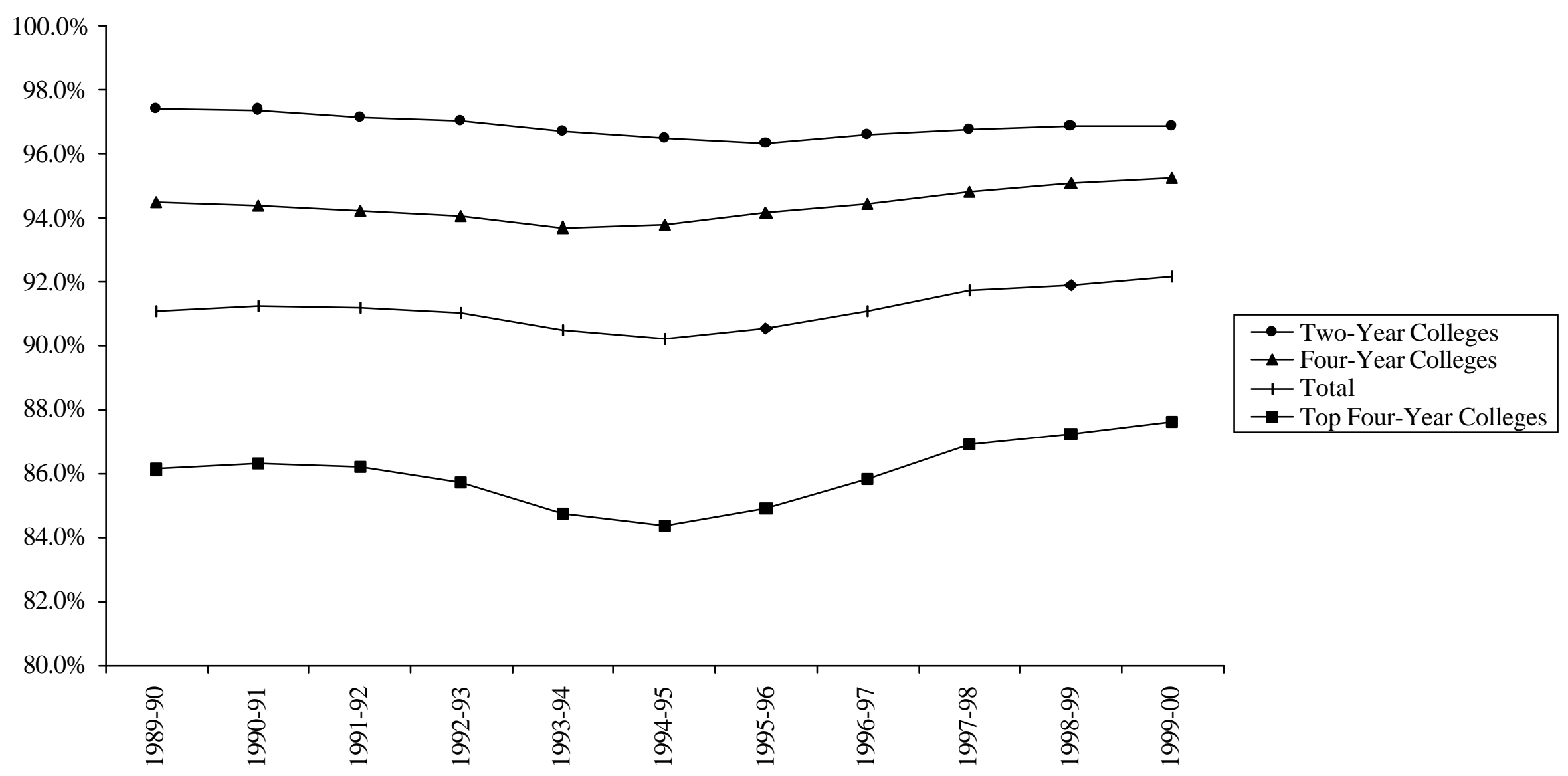

Source: University System of Georgia. 
Figure 5:

Log of Average Tuition, Fees, Room and Board

at Public 4-Year Schools

(\$1998)

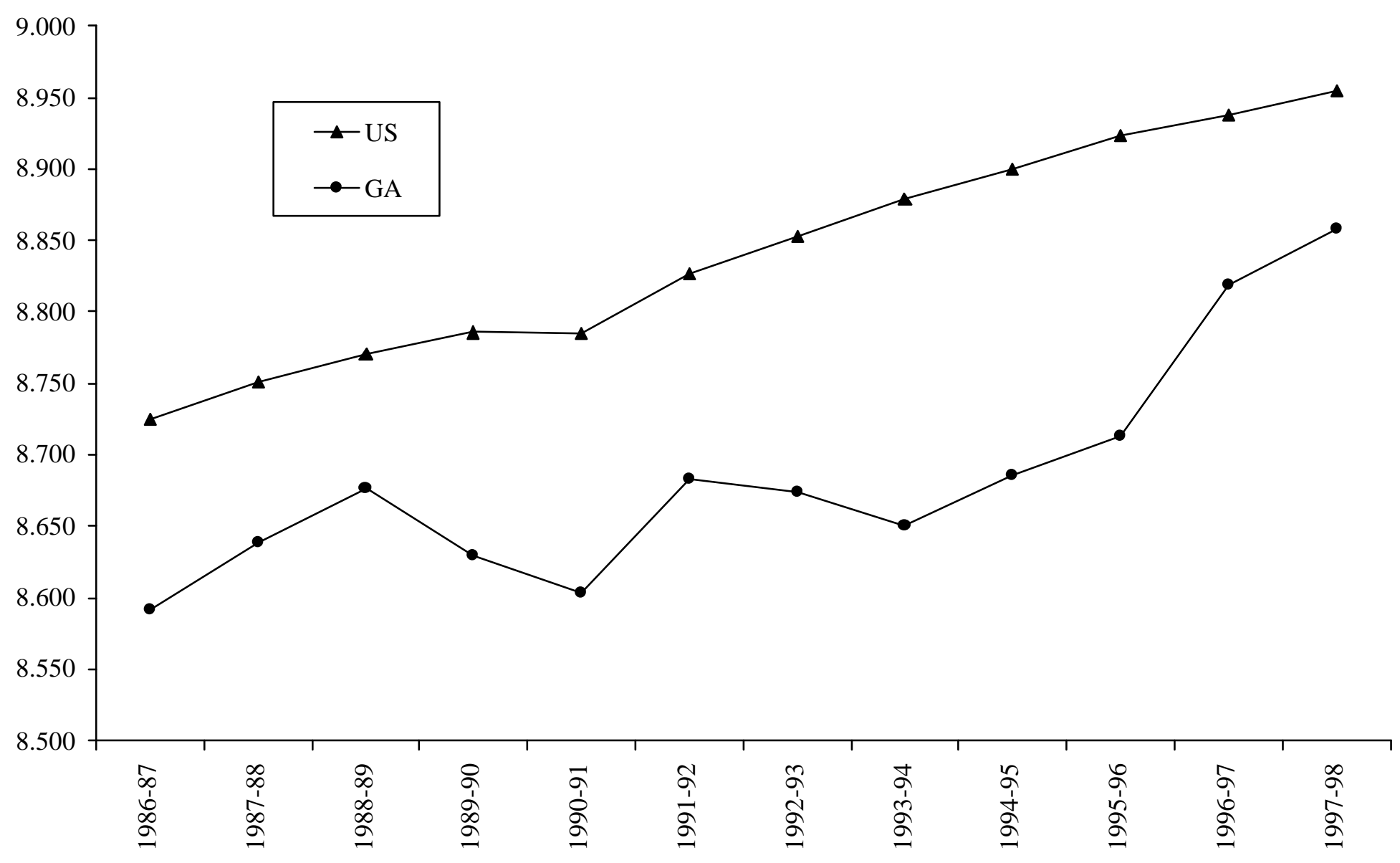

Source: Table 312 in National Center for Education Statistics (1998a) and Table 81 in National Center for Education Statistics (1998b). 
Figure 6:

Log of Average Tuition, Fees, Room and Board

at Private 4-Year Schools

(\$1998)

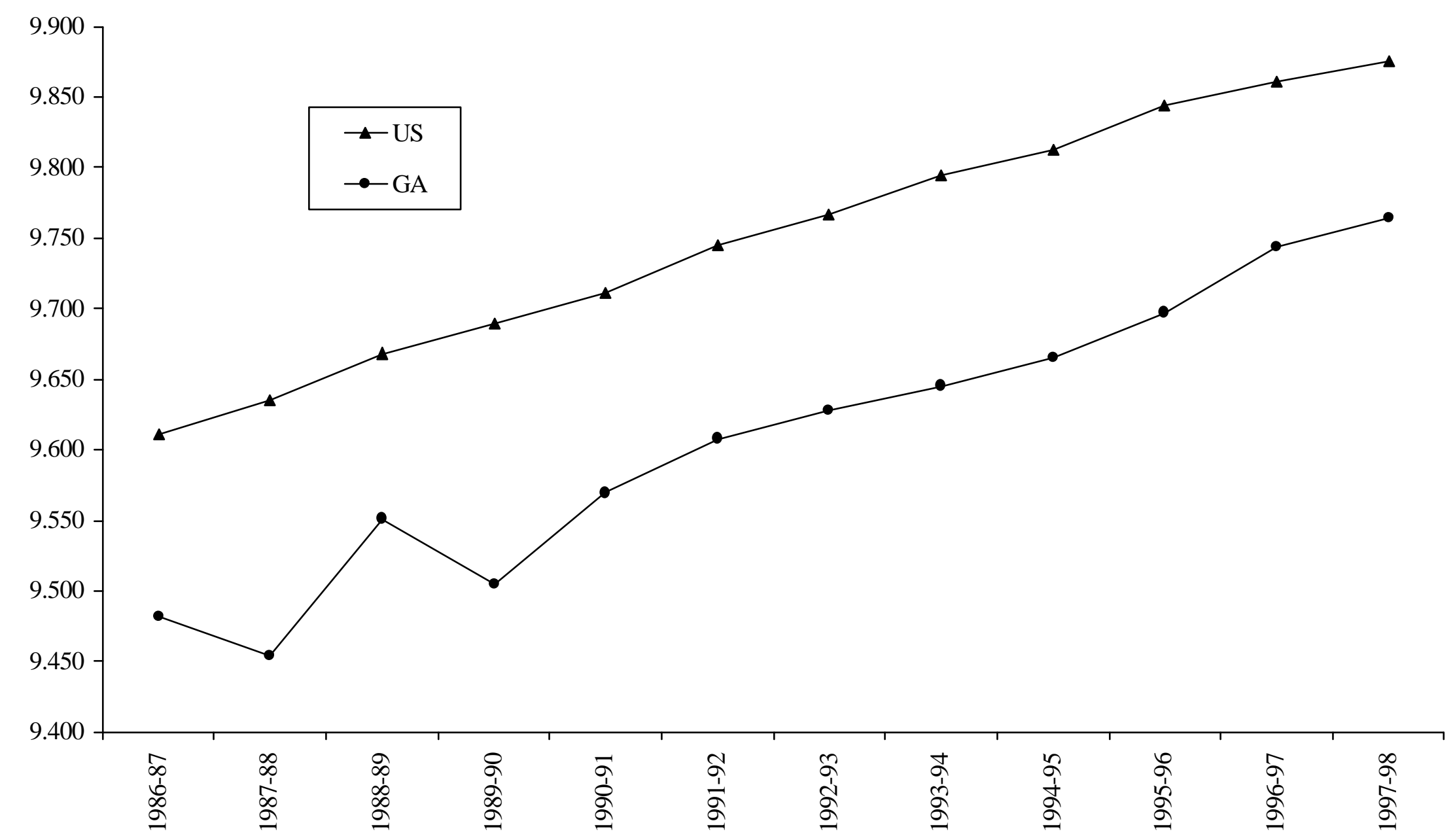

Source: Table 312 in National Center for Education Statistics (1998a) and Table 81 in National Center for Education Statistics (1998b). 